\title{
LETTERS OF CREDIT UNDER THE PROPOSED UNIFORM COMMERCIAL CODE: AN OPPORTUNITY MISSED
}

NiNeTY percent of the financing of international sales transactions is accomplished by means of the letter of credit. And the device now appears with increasing frequency in domestic trading as well.2 Recognizing the commercial importance of the letter of credit, the Commissioners on Uniform State Laws have attempted to codify letter of credit law in Article $5^{3}$ of

1. This estimate appears in Hoxtes. Intervational Rules on Letrers of Credir (ECA mem. 1950), and was substantiated by interviews of officials of leading banks in New York City, conducted by the Yale L.aw Jetravin, June and Sejtember, 1952 (hereinafter cited as Interviews). See also Note, Reriscd Intcrnational Rules for Documsntary Credit, 65 Harv. L. Rev. 1420 (1952).

Approximately nine-tenths of letter of credit financing is done in connection with internal trade. InTERnEN's. And the device is heing uesd extensively in the Mlutual Security Program. Corminuication to the Yale LaW Jotesall from Mr. Oscar Gray, member of the legal staff of the Department of State, dated November 15, 1952, in Yale Law Library.

2. Extension on wider scales into domestic financing has been predicted and urged. See Llewellyn, Some Adzastages of Letters of Credit, 2 J. of Bus., U. of Crit. 1, 6 (1929). And, in fact. domestic use has increased since the end of World War II, especially when a seller is dealing with a buyer for the first time. Frequent use of sued credits is made in automobile financing. Intenviews. See Wand \& Harfield, Banis CREDTtS AND ACCEFTaxces (3d ed. 194S) (hercinafter cited as Ward \& Hirriend). A growing practice is for the recipient of an international trade lctter of credit to use his rights under that credit as a basis to secure domestic financing through another, or as it is called "secondary," letter of credit. See id. at 140-6; Kingdom of Sucden v. New York Trust Co., 197 Misc. 431, 413, 96 N.Y.S.2d 779, 789 (Sup. Ct. 1949).

3. The first tentative draft of an Article dealing with letters of crcdit was submitted to the American Law Institute and National Conference on Uniform State Laws at their joint meeting, February 9-11, 1946 (hereinafter cited as 1946 Fen. Drafr). A secund draft, little changing the first, came out in October of $1776^{\circ}$ (hercinafter cited as 1946 OCT. DRAFT).

In May, 1949, a printed draft of the Code with comments appeared, treating letters of credit in Article 4. Axserican Law Institute, Nat. Conf. of Comsissro:ters o: Uniforai State Laws, Commerctal Code art. 4 (May, 1949 Draft) (hereinafter cited as 1949 DRAFT). The "proposed final" draft of the Code of Spring, 1950, submitted to tine Conference May 18-20, 1950 (hereinafter cited as 1450 DRAFr), containted the law on letters of credit in Article 5. A second "proprosed final" draft of the Code, containing a slightly revised version of the 1950 DRAFT of Article 5, was submitted to the National Conference at its meeting of May 16-19, 1951 (hereinafter cited as 1951 DRarr). A quicl revision of Article 5 was undertaken in the Summer of 1951. A considerably revised test of Article 5 appeared in what was supposcd to ba the final text edition of the Code and was approved by the American Law Institute and the Commissioners on Unifirm Laws at a joint meeting sponsored by the American Bar Assuciation in the Fall of 1951. The final edition containing official comments to all the articles-and for the first time the final comments to Article 5-was printed in September, 1952. (This final vcrsion. Arserscas: Law Instrtete, Nat. Conf. of Connissroners on Uniforar State Laws, Linfozes Cominesclal Cone: Official DRaft (text and comments ed 1952), is hereinafter citcd as Final LRaft or simply by section numbers.) 
the proposed Uniform Commercial Code. ${ }^{4}$ Their proposals warrant careful analysis and discussion.

\section{Operations of Letters of Credit}

The letter of credit ${ }^{5}$ is in principle a simple device. ${ }^{6}$ Typically, the seller of goods to a foreign buyer will ask for its use as the method of payment. ${ }^{7}$ The buyer is required to engage a bank in his own country to promise, without right of revocation, to honor drafts drawn by the seller, within a set time, up to a stipulated amount. ${ }^{8}$ In banking parlance the buyer is the

4. The Code has been the subject of much literature, not all of it unheated. Sce for general discussion, Beutel, The Proposed Uniform (?) Commercial Code Sthould Not Be Adopted, 61 Yale L.J. 334 (1952); Corbin, The Uniform Commercial Code-Sales: Should It Be Enacted?, 59 YAle L.J. 821 (1950); Gilmore, The Uniform Commercial Code: A Reply to Professor Beutel, 61 Yate L.J. 364 (1952). Article 5 as it appeared in the Spring Draft of 1950 was briefly appraised in McLaughlin, The Letter of Credit Provisions of the Proposed Uniform Commercial Code, 63 Harv. L. Rkv. 1373 (1950). Final Drafi (text without comments ed.) was treated more extensively in Harficld, Article 5-Trade Without Tears, or Around Lefters of Credit in 17 Scctions, [1952] WIS L. REv. 298.

5. "[A] commercial letter of credit may be defined as a letter wherein the writer agrees to pay a designated amount of money in cash in exchange for specified shipping documents." Kingdom of Sweden v. New York Trust Co., 197 Misc. 431, 441, 96 N.Y.S.2J 779, 787 (Sup. Ct. 1949).

6. For brief surveys of the evolution of letters of credit financing, see DAvis, Tur Law Relating to Commercial LetTers of Credit 1-11 (1939) (hereinafter cited as Davis) ; Gutteridge, The Law of Banker's Commercial Credits 1-15 (1932) (hercinafter cited as GutTeridge) ; Ward \& Harfietd 67-72; Finklestein, Performance of Calmditions under a Letter of Credit, 25 CoL. L. Rev. 724, 725-6 (1925); Mead, Doctimcilary Letters of Credit, 22 CoL. L. REv. 297, 298-9 (1922); Thayer, Irrevocable Credils in International Conmerce: Their Legal Natutre, 36 CoL. L. Rev. 1031 (1936); Trimble, The Law Merchant and the Letter of Credit, 61 HARv. L. Rev. 981 (1948); Comment, Letters of Credit-Negotiable Instruments, 36 YALE L.J. 245 (1926).

7. Operation of the documentary credits in foreign transactions is detailed in Davis 12-22; Gutteridge 1-9; O'Halloran, The ABC of Commerctal, Letters of Ciledir (1947); Finkelstein, Legal Aspects of Commercial Letters of Credit 14-24 (1930) (hereinafter cited as FINKELSTEIN) ; WARD \& HARFIELD 1-19. Especially helpful int understanding their mode of operation are Neidle \& Bishop, Commercial Letters of Credit: Effect of Suspension of Issuing Bank, 32 CoL. L. REv. 1 (1932); Thayer, Irrevocabli Letters of Credit in Modern Commerce: Some Practical Considcrations, 16 CAN. B. Rev. 79 (1938). See also, Harfield, supra note 4, at 299.

8. An exact sum, up to which the seller may draw, is stated. But provision is sometimes made that the credit automatically will renew itself; in that case, once an issuing bank has been reimbursed by the buyer, seller is free to draw drafts again up to the amount stated. This is the so-called "revolving credit." See American National Bank \& Trust Co. v. Banco Nacional De Nicaragua, 231 Ala. 614, 166 So. 8 (1936) ; Nordskoy v. National Bank, 10 Ll. L. Rep. 652 (1922). Davis 27; Gutteridge 12; Ward \& HallFIELD 31. 
"customer," the bank promising to honor drafts is the "issuer," and the seller is the "beneficiary."

As a rule the issuer will either notify the beneficiary directly that an irrevocable credit has been opened or will call upon a branch or correspondent bank in beneficiary's country to notify him. ${ }^{10}$ The notification form is the "letter of credit."11 Frequently the correspondent bank will engage to honor or pay drafts on behalf of the issuer without committing itself to any liability to the beneficiary. ${ }^{12}$ Or sometimes the notifying branch or correspondent will be asked to "confirm" the credit. ${ }^{13}$ It is then understood that

9. The Final DRAFt, as all earlier drafts of Article $\mathbf{5}$, uses these generally accepted terms:

$\$ 5-103(1)$ (d): "A 'beneficiary' is a person who, under the terms of a credit, is entitled to draw under it."

$\$ 5-103(1)(g)$ : 'A 'customer' is a buyer or other person who causes a bank to issue a credit."

\$5-103(1)(c): “An 'issuer' is a bank maling an engagement or giving a nutice as defined in subparagraph (a) of this Section [notice that it will honor draits]."

Other terms are commonly in use. The customer is often referred to as the "ascredited buyer or person," "consignee," "importer" and "account." Beneficiary is often termed "accreditee" or "seller." Issuer is frequently labeled "the opening banl:" or "issuing bank." See WARd \& HaRfIELD 21.

10. The usual practice is for a correspondent to notify the beneficiary. Sometimes the customer will be authorized to notify the beneficiary, a practice once ronular but now rarely used. See WARd \& Harfield 29-32; InTERviews. See also Ameriean Steel Corp. v. Irving National Bank, 266 Fed. 41 (2d Cir. 1920) (issuer natifies beneficiary directly); Prehn v. Royal Bank of Liverpool, [1870] L.R. 5 Ex. 92 (customer notifies beneficiary).

11. Standard forms are set out in WARD \& HaRfiend 165, 167, 168,170, 171; and Mead, Documentary Letters of Credit, 22 CoL L. Ker. 297, 313-31 (1922). Despite attempts at uniformity the forms used by banks differ widely. See Wand \& Harfield 156 et seq.; 1946 FEB. DRAFT 2.

12. Three distinct functions performed by a correspondent bank should be recognized and separated for purposes of analysis: correspondent only notifies of the opening of the credit (notifying or advising bank); correspondent confirms the credit (confirming bank); correspondent notifies but agrees with the issuer that it will honor (accepting bank) or pay drafts (paying bank).

See WaRd \& Harfield 22-32; Thayer, Irroocable Lotters of Credit in Modern Connmerce: Some Practical Considerations. 16 CAx. B. Rev. 79, s0-3 (1938).

The correspondent may also be asked on occasion to issue the letter uf credit fur the buyer's bank. In that case the correspondent is the actual issuer. E.g., Pan-.Imerican Bank \& Trust Co. v. National City Bank, 6 F.2d 762 (2d Cir. 1925).

13. The process of "confirming" a credit by notifying bank usually is done at the request of the beneficiary, who will want a bank in his jurisdiction tw become primarily: liable on the letter. Some difficulty arises in discussions, because the English practice is to speak of "confirmed" credits as any credit which is by its terms made irrevorable, whereas a "confirmed" credit in the United States alludes only and specifically to thise credits on which the correspondent as well as the issuer is liable to honor drafts drawn under the credit. See National Bank of Esypt v. Hannevig's Banl, Ltd., 1 Ll. L. Rep, 69 (C.A. 1919); and discussions in Dans 3S; Gutteridge 36. See also Wani \& HarFTELD 170. 
the correspondent bank is accepting an additional and independent liability to honor the drafts drawn by the beneficiary. ${ }^{14}$

In the "documentary" credit, the beneficiary must surrender required documents which describe and give control of the goods to the holder in order to receive payment or acceptance of the drafts. ${ }^{16}$ Documents most often required are commercial invoices, bills of lading, constlar invoices, and marine insurance papers. ${ }^{16}$ By contrast, in the "clean" credit, beneficiary need present no documents with the draft. ${ }^{17} \mathrm{~A}$ credit may combine both the "clean" and "documentary" forms by allowing beneficiary to draw a part of the total amount without surrender of documents. ${ }^{18}$ Most transactions, however, call for the documentary type.

14. INTERVIEWs. Acceptance of an independent liability by a confirming bank renders drafts drawn under the credit easier to negotiate, for holders of drafts will have two banks-the confirming bank and issuer-primarily liable on the drafts.

Confirmation now is rare when large United States banks are isstuers or paying banks. INTERviEws. This also appears to be true for the large London banks. Megrall, Commercial Letters of Credit, 102 L.J. NEws 410 (1952).

15. Typically the letter of credit is an ancillary transaction to a c.i.f. contract. Thus, the documents demanded are usually those required by a c.i.f. contract, although the documents may be easily varied. See Davis 126 et seq.; FEB. Draft 29 ; Brown, Documtutary Conditions of Payment in Commercial Letter of Credit, 13 Tulane L. Rev. 495 (1939). For international practices see Ward \& Harfirld 185 et seq. For the present Code provisions documents in c.i.f. contracts for overseas shipments see FinAL DrafT $\$ \$ 2.320$, $2-324$.

16. See International Chanber of Comarerce, Uniforas Custons and Practice for Commerctal Docunrentary Credits, arts. $15-48$ (rev. ed. 1951). The articles cited cover the nature and interpretation of documents used in letter of credit financing both in regard to overseas and inland traffic for those banks adhering to the customs.

See also Brown, Documentary Conditions of Payment in Commercial Letters of Credit, 13 Tulane L. Rev. 495, 497-505 (1939) ; Comment, Descriptions in Documents Tendered under Letters of Credit, 33 YaLE L.J. 651 (1924).

17. The "clean credit" is often termed an "open credit." It is used generally to cover bona fide shipments of goods but often in speculations in exchange or in financing of a seller who is in reality an agent for procurement of the buyer. Perhaps it is more commonly used by English merchants than American. See Gutreridge 11-12 (English); WARD \& HARFIEID 9 (American).

Actually, the so-called "red clause" credit, formerly used mainly in the Far East fur trade and now used quite often in Australian trade, is a form of "clean" credit. INTERviEws. The seller is in effect buyer's agent going out to buy at the best price. But the buyer will not know the documents that will be obtainable and specifications in advance. And he may desire to finance a trusted agent. Consequently, he will allow the beneficiary, by a clause at one time written in red, to draw drafts under the credit, with the understanding that documents will be sent at a later date. For problems arising under the red clatuses and variations, see WARD \& HARFIEID 132-6 (a reprint of Harfield, Secondary Uses of Commercial Credits, 44 CoL. L. REv. 899 (1944) ); see also Oelbermann v. National City Bank, 79 F.2d 534 (2d Cir.), cert. denied, 298 U.S. 654 (1935).

18. This method of making advances to beneficiary by way of part clean and part documentary credits is probably seen best in the variants possible under red clauses. See WARD \& HARFIELD 132-6. 
Letters of credit usually permit the beneficiary to negotiate drafts, accompanied by required documents, to third parties. ${ }^{10}$ Hence, the beneficiary will often discount drafts ${ }^{20}$ with a local bank or with a notifying correspondent bank not specifically obligated to honor drafts under the terms of the credit..2 To receive payment or acceptance on a documentary credit, the third party will still have to present necessary documents along with the drafts.?

\section{Advantages of Letter of Credit Financing 23}

The letter of credit offers advantages to both seller and buyer. First, the seller of goods has the primary promise of a bank, ${ }^{23}$ rather than merely his

19. INTERVIEws. The notification form typically states: "We hereby agree with the drawers, endorsers and bona fide holders of drafts drawn and negotiated under and in compliance with the terms of this credit that the same will be duly honored on due presentment to the drawee." See the forms of the Corn Exchange Trust Company of New York City, on file in Yale Law Library; and standard forms in Wand \& Harrielo 165.

20. The drafts may be drawn on the issuer, or its paying bank, or the customer. They may be time drafts or sight drafts. When time drafts are drawn, the eustumer usually is required to make funds available to the issuer by the last business day before the drafts mature. See form for opening the credit used by the Corn Exchange Banls of New York City, on file in Yale Law Library; WARD \& Harsmend 111; Continental Nat. Banl: v. National City Bank, 69 F.2d 312 (9th Cir. 1934). Customers may make funds available for sight drafts either before or after payment.

21. Although at one time there was a dispute as to whether the drafts could be negotiated to anyone except a bank, the assumption now seems to be that they can be negotiated to anyone. INTERVIEWs.

22. An important distinction is to be made between negotiation of drafts already accepted by a bank obligated to accept under a letter of credit, and negotiation of draits along with the required documents before acceptance. The former falls under general negotiable instruments law. Incidences are not exactly alike: c.g., it is accepted that nobody but the beneficiary can present drafts and documents and receive rayment, or have the drafts honored before acceptance, mlnless the terms of the credit (expressly or impliedly) so permit. See Eriksson v. Refiners Export Co., 264 App. Div. 525, 528, 35 N.Y.S.2d 829, 832-3 (1st Dep't 1942).

23. Alternative methods of financing-cash with order, promissory notes, open or book credit, trade acceptances, use of order bills, etc--are compared with letters of credit in McCurdy, Commercial Letters of Credit, 35 HARv. L. Rev. 539, 541. See also Davis 13-15; Ward \& Harfield 3-8; Westerfield, Money Credit \& Banking 483 et seq. (1938) ; Llewellyn, Some Adz'antages of Letters of Credit, 2 J. Bus., U. of Cur. 1, 11-15 (1929) ; Thayer, Irrezocable Letters of Cridit in Modirn Commerce: Some Practioal Considerations, 16 CAN. B. Rev. 79 (1938); Note, 21 CoL. L. Rev. 176, 170 (1921).

It is the general conclusion that no alternative to letters of credit uffers to the seller the combination of assured payment, no credit strain, and immediate payment upon shipment. See also Kingdom of Sweden v. New Yorls Trust Co., 197 Mise. 431, 441-2, 97 N.Y.S.2d 779, 788 (Sup. Ct. 1949).

24. The letter of credit makes the issuing bank primarily liable. E.g., Decatur Bank: v. St. Louis Bank, 21 Wall. 294 (U.S. 1874) : Border Nat. Banls v. American Nat. Banls, 282 Fed. 73 (5th Cir.), cert. denied, 260 U.S. 701, 732 (1922) : Pan-American Banls v. National City Bank, 6 F.2d 762 (2d Cir.), cert. denicd, 269 U.S. 554 (1925). Xational banks are now unquestionably able to issue letters of credit. See Trimble, The lmsilisd 
buyer, that he will be paid.25 Consequently, he is able to enter markets where the risk of dealing with an unknown buyer would otherwise be too great. ${ }^{20}$ Secondly, by presenting sight drafts or by negotiating his drafts, the seller obtains payment immediately upon shipment, freeing capital for other transactions. Finally, he may use an irrevocable letter of credit as means of securing ad-

Power of National Banks to Issue Letters of Credit and Accopt Bills, 58 Y YLE L.J. 713 (1949) (an effective argument that national banks have had the power to issue foreign and domestic letters of credit since the National Bank Act of 1864, although it has been maintained that this power came only by implication with passage of the Federal Reserve Act in 1914). See also paper by Professor Llewellyn quoted at length in WARD \& HAllFIELD 68-72 (national banks' power to issue derives "from the nature of the business of banking" and does not depend on the Federal Reserve Act). Contra: Finketstern 5; Whitaker, Foreign Exchange 134 (1922) ; York, International Excirange 298-300 (1923) (national banks may now issue letters of credit but that power is derived from implications in the Federal Reserve Act).

The power is specifically given to federal banks engaging in foreign transactions, 41 StaT. 378 (1919), 12 U.S.C. $\$ 615$ (1946).

Most of the states now have specific statutes authorizing state banks to issuc letters of credit, domestic or foreign, although limitations as to aggregate amounts and amounts to any one person are typically placed upon the banks. See, e.g., N.Y. BANking Law $\S 96(2)$.

The argument that a bank cannot issue letters of credit without statutory authorization is based on the idea that banks cannot lend their credit. 1 MORSE, BANKS AND BANking $\$ 65$ (6th ed. 1928); contra: WARD \& HARFIED 72 . It may well be doubted that courts would strike down letters of credit in states not specifically authorizing their issue since such authorization can easily be implied from statutes of the states authorizing bank acceptances of drafts, or from the general nature of banks as Professor Llewellyn argues. But see Campbell, Guaranties and the Suretyship Phases of Letters of Credit, 85 U. of PA. L. REv. 261, 291-5 (1937).

25. The case law in the United States seems to view stipulation of payment by means of a letter of credit as not relieving the buyer from his commitment on the underlying contract should seller be unable to collect any or part of the sales price by means of the letter of credit, unless the credit clearly so stipulates. Lamborn v. Allen Kirkpatrick \& Co., 288 Pa. 114, 135 Atl. 541 (1927) ; Dickerman v. Ohashi Importing Co., 63 Cal. App. 101, 218 Pac. 458 (1923); Bell v. Moss, 5 Whart. 189 (Pa. 1840). See also Greenough v. Munroe, 53 F.2d 362, 364 (2d Cir. 1931). And see Note, 40 HARv. L. Rrv. 294 (1926). The Code apparently intends to maintain this rule. See Finst. DrafT \$2-325(2) and comment.

26. The basic object of seller is to protect himself from all the vagaries of dealing with foreign buyers. Often buyer will be unknown. The risks are many:

"In the first place, he [buyer] may cancel . . . during or immediately after the pro. cess of manufacture ... or after purchase to fill the order. In the second place, he may reject the goods on arrival ... and then use seller's necessity as a means of bargaining. ... Moreover, credit terms in foreign trade are typically long, and the absence of credit information ... makes the buyer's acceptance, even when obtained, no safe assurance of ultimate payment. Finally ... those unforeseen changes in the market from which commercial disputes flower, and which are also a potent source both of fraud and of buyer's insolvency, are likely to occur without notice. . . [T] heir fruit is trouble, even where buyer was originally acting in good faith." Llewellyn, Some Adrantages of Letters of Credit, 2 J. of Bus., U. of Cri. 1, 6 (1929).

A promise of payment from one of the large issuing banks throws the risk on the bank. See also Westerfield, Money, Credit \& Banking 483 et seq. (1938). 
vances to finance his end of the transaction. ${ }^{27}$ Thus, the seller, in effect, often uses the buyer's line of credit to finance a transaction from which both will profit.

The buyer also benefits from use of the documentary letter of credit. As a means of financing his venture the credit is cheap ${ }^{25}$ and efficient. The issuer extends the credit cheaply, in part, because the obligation of the buyer is at all times secured. Once the beneficiary or any presenter of drafts has turned over required shipping documents to the issuer, the latter continues to hold title to the goods until their arrival at the port of destination. ${ }^{3}$ Depending on the arrangement between buyer and issuer, the goods may then be either turned over to the buyer upon immediate payment, or given to him for resale against a trust receipt ${ }^{30}$ with the issuer retaining legal title until the goods are sold. Thus, unless the issuing bank requires additional security; the buyer also has the advantage of having his working capital unencumbered. He may secure and pay his obligation to the bank out of the proceeds from the goods. 31

27. One of the most significant developments in letters of credit is their use to finance buyer's operations. Letters of credit are not negotiable instruments themselves. But various methods of transferring the benefits are available: (1) negotiating drafts under the credit; (2) "red clauses" (see note 17 stpra) ; (3) assignment of the credit (when permitted); (4) assignment of the proceeds; (5) secondary or "back to bacl:" letters of credit; (6) general improvement of the seller's credit standing by having the assurance of credit. See WARD \& Harfierd 12S-46 (reprint of Harfield, Sccondary Uses of Conmercial Credits, 4 Col L. Rev. $\$ 99$ (1944)); MicGowan, Assignability of Doctmentary Credits, 13 Law \& Conterip. Prob. 666 (1948).

28. Bank fees for opening the letter of credit may be as little as une-tenth of one percent of the face amount of the drafts, and for confirming a letter of credit as little as one-twentieth of one percent. The cost will depend, among other factors, on (1) the credit standing of the buyer; (2) the nature of the bank's duties-whether typieal or rcquiring additional functions; (3) the nature of the trade; (4) distances and countries involved; (5) the duration of the credit; (6) the amount of credit. INTEBribws.

29. The bill of lading accompanying drafts under the documentary credit are documents of title. So long as the bank continues to hold the bill of lading it has control over the goods. Thus the goods secure buyer's abligation to the bank. Sec Miaurice O'Meara Co. v. National Park Bank, 239 N.Y. 386, 402, 146 N.E. 636, 641 (1925) (dissenting opinion). But conservative banking practices will primarily rely on buyer's general credit standing or other security. INTERvIEwS.

Fival DRAFT, art. 7, codifies the law on bills of lading and other doeuments of title.

30. A typical trust receipt is set out in WARD \& HARFIEzD 107. For a comprehensive study of trust receipts, see MoGowan, Trust Receirts (1947). Finil Drifr, art. 9, covering secured transactions, deals with trust receipts. It will necessitate repeal of the Uniform Trust Receipts Act wherever in force. Final. DRAFT $\$ 10-102$.

31. The buyer may delay reimbursement according to the terms of his agreement with the issuer-typically until the day before maturity. In effect he is initially financing his transaction by means of an executory contract-a step further removed than inventory financing.

The major burden falling on the buyer is the possibility that the seller might furnich defective goods and thus he, the buyer, will have to come fortward to litigate. Rut the 


\section{Codification of the Law of Letters of Credit}

An early effort to establish a uniform system for regulating letters of credit was made by the International Chamber of Commerce in 1933 by the publication of the Uniform Customs and Practice for Commercial Documcntary Credits. ${ }^{32}$ Although endorsed by leading American banks, the Customs have

buyer may protect himself by requiring as a condition to honoring drafts under the credit third party certificates of quality, signed by a person of responsibility at the place of shipment. When buyer so stipulates the issuer must of course obtain such certificates if the issuer is to be reimbursed by the buyer. See Laudisi v. American Exchange Nat. Bank, 239 N.Y. 234, 236, 146 N.E. 347, 349 (1924); Davis 9; Comment, The Rights of the Seller under a Documentary Letter of Credit, 34 YALE L.J. 775, 782 (1925).

The buyer may further protect himself by having the credit issued for only a percentage of the price stipulated in the underlying contract. Complete payment would then depend upon conformity of the goods to the contract.

32. The history of attempts by bankers to bring uniformity of forms and practices is traced in WARD \& Harfietd 147-99. See also Ward \& Rosenthal, The Necd for the Uniform Commercial Code in Foreign Trade, 63 HARv. L. Rev. 589 (1950) ; Note, Revised Rules for Documentary Credits, 65 Harv. L. Rev. 1420 (1952).

A major step was taken when a report of a special committee of the International Chamber of Commerce was published in May, 1930. The Seventh Congress of the International Chamber of Commerce approved the report in 1933. They were published as International Chamber of Commerce, Uniform Customs and Practice for CommiERCial. Credits, Brochure No. 82 (1933). Many of the leading American banks adopted the Customs in part in July of 1938, effective as of October 1, 1938. Only English and Commonwealth banks, among the leading users of credits, wholly failed to adopt the 1933 Customs.

But the adoption by the American banks at this stage only applied to "export" credits -i.e., credits wherein beneficiary is exporting and the United States banks are advising or opening credits for foreign correspondents or principals. Furthermore, the American adoption was made subject to certain "Guiding Provisions." See WARd \& HARFIELD 196. 8. And the various chamber of commerce committees in some of the countries have from time to time amended the application to meet trade practices in the particular country, notably the United States in 1946.

In June, 1951, the Thirteenth Congress of the International Chamber of Commercc generally revised the rules to meet changing practices. INTERNATIONAL CuAMUER OF COMaerce, Revision of the Uniform Customs and Practice for Commerctal Documentary Credits, Brochure No. 151 (1951) (hereinafter cited as ICC Custons).

American banks have adhered to the new rules since January 1, 1952. Twenty-nine countries have adopted the revisions as of September, 1952. InTERviews. Sec list it Backus \& Harfield, Custom and Letters of Credit: The Dixon, Irmoas Case, 52 Cot. L. REv. 589, 591 n.11 (1952). English and Commonwealth banks here again refused to adopt the Customs. Ibid.

The practice of United States banks is to incorporate in their export credits a clattse making the ICC Customs applicable. The courts give effect to such provisions. Sec, $c_{\text {.g. }}$, Dixon, Irmaos \& Cia. v. Chase Nat. Bank, 144 F.2d 759 (2d Cir. 1944), cert. denicd, 324 U.S. 850 (1945); Eriksson v. Refiners Export Co., 264 App. Div. 525, 35 N.Y.S.2d 829) (1st Dep't 1942).

Other less successful attempts at setting out uniform rules are detailed in WARD \& Harfield 147-99. For a recent example, see Internationat Chasmder of Comaerce, Standard Forms for the Opening of Documentary Crepits, Brochure No. 15\% (1951). 
until recently been utilized in the United States only for notification to exporters. ${ }^{33}$ And even to the extent that the Customs are used, and despite 1951 revision, ${ }^{34}$ the provisions have proved difficult to interpret. ${ }^{35}$ MIoreuver, the Customs are rarely, if ever, used for domestic credits. ${ }^{30}$

Article 5 of the Uniform Commercial Code represents the latest attempt in the United States to establish uniform rules applicable to all types of.dacumentary credits. The rules drafted were designed not only to cover international transactions but also domestic transactions. ${ }^{37}$

In drafting this article, the codifiers worked with certain policy considerations. Breadth and flexibility were necessary ${ }^{38}$ to avoid undue interference with banking practices and present international accord. ${ }^{30}$ At the same time,

33. Many of the large issuers in the New York area have approved the idea of adopting the ICC CusTous for all credits, including import credits. Some actually have begun to incorporate the provision into the import credits as guiding principles. But probably less than half the New York banks do so. And the percentage outside the New York area is considerably smaller. InTERviews. See Note, 65 Hasv. L. Rev. 1420, 1422 n.14 (1952).

34. Major revisions were made in arts. 5, 10, 15, 18, 28, and 29 .

35. See in general ECA, Tech. Assist. Drv., Discussron of Projectio Progrus for Classification of International Baning Practices (Mmutrs) (OEEC No. 31, 1950). See also Kingdom of Sweden v. New York Trust Co., 197 Mise. 431, 90 N.Y.S.2d 779 (Sup. Ct. 1949) (ICC Custusrs, art. 49 interprcted).

36. The ICC Custors are the chief crystallization of internstional practices.

For a recent extreme example of the informality of domestic credits, see Consolidated Sales Co. v. Bank of Hampton Roads, 193 Va. 307, 68 S.E.2d 652 (1952) (first Virginia Supreme Court case on letters of credit). And see Epps \& Chappell, Assimilation of the Letter of Credit by the Common Law, $A$ Case of Legal Indigestion, 38 VA. L. Rex. 531 (1952); Note, Letter of Credit Construed Against the Basher, 69 Basmmo LJ. 187 (1952).

37. Final Draft \$ 5-101, comment.

38. Flexibility is a problem for any codification. It is especially troublesome in the field of commercial law where practices may change completely in the course of a few years. The forms and meaning of bills of lading for example have been particularly susceptible to change. See Gilmore, On the Difficultics of Codifyimg Commcrial Law, 57 YALE L.J. 1341 (1948).

39. However, the objection to the Code's establishment of rules different from the ICC Cistous on the ground that it would establish one set of rules for the United States and another for the rest of the world does not hold up; for, as matters now stand, there can be, and are, any number of different rules of construction in the United States, varying from jurisdiction to jurisdiction and depending on local practices and terms of the contract. And different rules are even applied to banks adhering to the ICC Custurss, depending on whether the credit is "export" or "import." Furthermore, the simple addition of the phrase, "unless otherwise agreed," to the sections avoids any actual conflict. Sce, e.g., Final Draft $\$$ 5-111. In addition one commentator has pointed out:

"As long as the present 'seller's market' continues, Americans will write the terms of sale, and those dealing with us will necessarily become used to the construction which we place on letters of credit. In addition, it is by no means certain that letters of credit will be confined to international comnerce. . ." MfeLaughlin, The Lefter of Credit Procisions of the Proposed Unifarn Code, 03 H.as. L. Rav. 1373, 1375-6) (1950). 
precision and attention to detail were requisities to clarification of the rights and obligations of the parties. ${ }^{40}$ One important goal was to maintain present low banking charges by avoiding major shifts of liability from commercial parties to banks. ${ }^{41}$ Yet this objective had to be balanced against the clesirability of making parties responsible for acts which they control. This Comment will attempt first in a general way to examine some of the most significant features of the draftsmanship and scope of the Code. It will then turn to a more intensive analysis of important provisions in three specific areas which have been particularly troublesome in letter of credit transactions: conformity of documents; the relationship between the letter of credit and the underlying sales agreement; and recovery of damages from the issuing bank. The analysis should be read in the light of the unparalleled opportunity open to the drafters to resolve present problems and to effect desirable changes.

\section{Draftsmanship}

Draftsmanship and Scope of the Code

By adopting a relatively limited number of definitions of parties to letter of credit transactions, ${ }^{42}$ the Code has avoided the verbal labyrinth which has befuddled much of the literature in the field. In the past, classifications of credits such as "import" and "export" credits, "circular" and "negotiation" credits, and other types, ${ }^{43}$ have unduly complicated understanding of relation-

40. One of the hopes in codification of the letters of credit law was to furnish a careful handbook through the legal maze surrounding their use. See McLaughlin, supra note 39 , at 1375 .

One important function of Article 5 might have been to eliminate the present forms used to open the credit ("requesting forms"). Typically, they are simple on the front but contain a string of finely printed complex clauses on the reverse side. See Waw \& Harfierd 179-83 (standard application form set out); and requesting forms on file in the Yale Law Library.

"An executive of an issuing bank, during the course of a conversation with the writers, remarked that the only part of the agreement intelligible to the bank's customers is the space provided for his signature." Neidle \& Bishop, Commercial Letters of Crcdit: Effect of Suspension of Issting Bank, 32 CoL. L. REv. 1, 4 n.10 (1932) (onesidedness of the bank forms, protecting the banks fully but not their customers, also criticized).

41. One of the prime advantages of letters of credit is their low cost. The fict that the banks take minimal liability under the credit agreement is one of the chief factors in the low cost of financing, according to most bankers. InTERviews. Sce WANo \& HAKFIELD 34; Strong, Import Financing by Letter of Credit, 61 BANkeRs MonTHLY 43!? (1944). See note 28 supra.

42. Final Draft $\$ 5-103(1)$ contains seven definitions indigenous to letters of credit. They are brief and clearly worded. See note 9 supra. But see text at notes 55-6 infra.

The conciseness and clarity of style of the 1949 DRAFT was praised in McLattghlin, The Letter of Credit Provisions of the Proposed Uniform Commercial Code, 63 HARv. L. REv. 1373, 1381 (1950).

43. The approach of Article 5 in terms of the operation of letters of credit avoids the use of the following common definitions and classifications, some of which have con- 
ships among various parties. ${ }^{44}$ Except for using the terms "authority to pay," "authority to purchase," 4 "5 and "revocable" and "irrevocable" credits, 5 aroids all classifications of letters of credit. Instead, it details the rights of the parties under documentary credits by codification of the rights and duties of "customer," "issuer," and "confirming," "advising,"'12 "paying," "accepting," and "negotiating" banks. But the last three terms are used by the Code without formal definition. 48 So the courts will apparently have to look to common usage for meaning. ${ }^{49}$

By careful use of their terms, the codifiers might have been able to spell out understandably the relationships among the parties. It several points, however, they neglected to employ terminology with precisiun. For example, under the definitional section of Article 5, a "confirming" bank assumes a "direct obligation under the credit." Although certain other sections recugnize this obligation by placing such a bank in the position of an issuer, Section 5-116 gives a holder of documentary drafts merely the right to ste the issuer for wrongful dishonor or repudiation. No reference is made to a "confirming" bank. Surely a court applying the Code would ignore the obviously unintentional slip and allow sinilar recovery against a confirming

fused discussion and are often inesactly used: crfort and import credits (sce Wuro \& H.rffield 27; Mead, Documcintary Leitcrs of Cridit. 22 CoL. L. Rev. 297, 299 (1922)); circular credits (see Union Bank v. Coster, 3 N.Y. 203 (1850); Dars 24); sfecial credits (see Eriksson v. Refiners Export Co., 264 App. Div. 525, 528, 35 N.Y.S.2d 829, 832 (1st Dep't 1942)); rcvolving crcdits (ste note S supra); sfecially adziscd (sce WARD \& HakfIELD 169); straight crodits (see Wans \& Haksiend 39); negotictions credits (see Davis 105; WARD \& HinfIELD 29); gcheral credits (sce 1946 Fen. DRirT 6-7); packing or anticipatory credits (see GtTTERTGE 13); Londos: acceptance credits (sce Spalding, Foretgar Exchaxige and Foreign Bills 237-8 (Sth ed. 1932)) ; ommibus credits (see $i d$. at 239).

44. The New York Bankers Commercial Credit Conference has used the variuts classifications to label standard forms which were approved by the Ameriean .1ceegtance Council in 1922, but which have not been formally adopted by bankers. Some ui the labals read: Circular Irrevocable Credit; Correspondent's Irrevocable Straight Credit; Confirmed Irrevocable Negotiation Credit. They have, however, set a general pattern. See WARD \& HARFIEID 11.

45. $\$ 5-104$.

46. $\S 5-105$. See also $\$ \S 5-106(b),(c)$.

47. $\$ 5-103$ (g) (customer); $\$ 5-103$ (c) (issuer); \$ 5-113 (f) (cunfirming banl;); \$ 5-103 (e) (advising bank).

48. The words appear in the body of the Article: yaying bank- $\$ 5-107(2)$; negotiating bank-\$ 5-107(2), 5-110; accepting bank-\$5-107(2).

The term "collecting bank" also slips in at $\$ 5-110$. But this torm is covered in Article 4 (bank collection article), Fivas DRAFT $\$ 4-105$ (d), although the codifiers neglceth to cross-reference the definition.

49. $\S 5-102(3)$.

50. $\$ 5-103(\mathrm{f})$.

51. § 5-111 (fraud and forgery); $\$ 5-107(2)$ (reimbursement); $\$$-110 (warranty and inspection); $\$ 5-117$ (insolvency) ; \$ 5-115(2) (assignment). 
bank. But this minor slip is one of a number of slight oversights. ${ }^{62}$ At another point, the term "advising bank" is used in connection with payment and reimbursement under the credit ${ }^{53}$-situations in which the term would have no relevance if applied according to best banking usage. ${ }^{54}$ And the Code's definition of "customer" is so broad that it could be interpreted to include a bank which has, for its own customer, procured issuance of a credit from another bank.55 Since the two banks do not generally stand in such an issuer-customer relationship, the definition may obscure their true relationship. ${ }^{56}$

52. See further $\$ 5-107$ (1) (honor section: issuer named but not confirming bank); § 5-110 (warranty section: no mention of paying or accepting banks; but use of advising bank, perhaps, to include them) ; \$ 5-107(2) (no mention of right of confirming bank to reimbursement).

53. Article 5 refers to advising banks in the genuineness of documents ( $\$ 5-110(1)$ ) and insolvency (\$5-117(1)) sections. But a purely advising bank is never involved in the financial arrangement of credits. An advising bank does become involved, of course, when it negotiates (discounts) drafts for the beneficiary; but then it becomes a "negotiating" bank, a term also used by the Code. It is again involved in financial problems when it is authorized at the request of the issuer to pay or accept drafts drawn either on itself or the issuer. But then the bank is a so-called "paying" or "accepting bank," terms also used by Article 5. See note 12 supra. Article 5 seems to use "advising bank" in a generic sense to include paying, accepting, and, perhaps, confirming bank. Sec broad definition, § 5-103(e).

54. As agent of issuer, conceivably an advising bank might not be allowed to profit from its position by discounting drafts under credits it has notified. Cf. Andrews v. Ramsay, [1903] 2 K.B. 635. But courts have recognized that the commercial value of advising credits through correspondents lies in the probability that beneficiary will dis. count drafts with the notifier. Consequently they have held that a purcly advising bank's agency ends with notification and it is then free to discount. Courteen Seed Co. v. Hongkong \& Shanghai Banking Corp., 245 N.Y. 377, 157 N.E. 272 (1927). On the other hand, when the notifying bank is one requested by issuer to pay or accept drafts under an irrevocable credit-that is, a "paying" or "accepting" bank-it pays in full under present commercial practice. Discounting would be a fraud on the beneficiary. The Code should have made it clear that "advising" bank refers to a bank which is motifying issuance of the credit but nothing more. And it should have codified the bank's right to discount.

55. By definition in $\$ 5-103$, a "buyer or other person" causing a credit to be issued is a "customer" under the Code. A bank requesting an issuer to open a credit for a buyer could perhaps fall under the definition, since "person" under the Code includes corporations.

56. Yet forms now in use by the Irving Trust Company of New York, typical of those in general use in New York, call for the buyer to fill out the requesting application, which is sent to the buyer's bank. This application names Irving 'Trust Company as correspondent of the buyer's bank, although Irving is actually to establish the credit. Buyer's Bank must then fill out a form entitled Appolntnsent Inving Trust Conpan: Agent To Establish Commercial Credit. The latter form assigns "as security" all the rights of the buyer's bank under the application. It gives Irving the right to demand additional security as it may request; and it gives Irving a lien on all of the buyer's bank's property-including deposit balances-for the amount of any liability that may arise under the credit. Such provisions do not jibe with making the buyer's bank a 
For a document that has undergone extensive examination and revision, Article 5 is not well drawn. The present draftsmanship adds little to its usefulness as a handbook of the law ${ }^{5 T}$ and practices; and it may, in fact, unnecessarily create confusion.

\section{Scope}

Article 5 is intended to cover uses of the letter of credit in domestic as well as international transactions. ${ }^{\text {ts }}$ Despite this broad scope, preoccupation

customer of the issuer under the Code. For example, under the Irving form Irving looks to the buyer for reimbursement initially; and reimbursement from buyer's bant: comes only in default of the buyer.

In view of the silence of the official comments, the codifiers probably did not consider possible application of the definition of "customer" to the "requesting" banl: (buyer's bank). See deliberate inclusion of requesting banks in the insolvency provisions. Frias. DRAFT § 5-117.

The best view would perhaps let the definitions of the Code guide on a functional basis. Irving, and all banks actually performing the duties of an issuer, are thus "issuers," and the buyers in all cases are "customers." The requesting bank should be leit to the contractual obligation of the forms and the common law of agency or surctyship and not fitted under the Code at all. With the requesting bank technique growing in importance, it is unfortunate that the Code did not try to spell out the relationships to promute understanding and prevent untoward court decisions.

The contracts employed by issuers dealing with requesting banlss are aimcd primarily at avoiding the allegation that the banks are acting ultra gires in guarantecing the debt of another. See Finkerstern 39-40; note 24 supro.

57. One provision, however, may help by-pass a voluminous amount of confusing literature devoted to attempting to tie the letter of credit with contract theory. Section 5-106(1) eliminates the need for consideration doctrine to establish the credit. In general, despite early English precedent (c.g., Phillans and Rose v. Van Mfierop and Hogtsins, 3 Burr. 1663, 97 Eng. Rep. 1035 (K.B. 1765)), the cases and some of the communtaturo have continued to tailor contract doctrine to cover the letter of credit transaction. The particular problem was one of finding consideration to support the irrevocable promite of the bank to honor beneficiary's drafts. The better view has always been to treat the letter of credit as a "mercantile specialty" free from contract doctrine. See discussion in Finfalstein 279 et. seq.; 11cCurdy, Commerial Lettcrs of Crcdit, 35 Hasw. L. Ra. 539, 564 (1922) ; Thayer, Irrevocable Credits in International Commerec: Thcir Logal Nature, 36 CoL. L. Rev. 1031 (1936); Trimble, The Law Merchant asd the Letter of Credit, 61 Harv. L. Kev. 981 (1948). Comparc Moss v. Old Colony Trust C0., 24t Mass. 139, 140 N.E. 803 (1923) (unilateral contract), with Carnegie v. Mrorrison, 2 Metc. 391 (IIass. 1841) (third party beneficiary), with Johannessen v. MIunroe, 158 N.Y. 641,53 N.E. 535 (1899) (estoppel theory).

58. § 5-101, comment.

The Code also covers to some extent the donestic use of international trade crediti.e., use of the credit as a financing device by the beneficiary. Specifically, $\$$ 5-115(1) permits unlimited transfer of the power to draw of the credit by the beneficiary should the customer and issuer be willing to permit. This goes a step further than the ICC Custoxss, art. 49, which permits only one transfer. The gresumption is against puwer to transfer unless otherwise indicated; so the Code strikes a balance between sterilizing transfer and the somewhat exaggerated fear of free transfer. For an excellent discursios, see McGowan, Assignability of Documentary Credits, 13 LAw \& Co:irens. Pros. 660 
with international practices has perhaps led the drafters to overlook some of the implications of its provisions on domestic trade. Section 5-105 states a conclusive presumption that a credit is revocable unless clearly designated as irrevocable. While international credits as a rule are clearly marked as revocable or irrevocable, ${ }^{50}$ letters of credit in domestic transactions are often ambiguous. ${ }^{00}$ As a result, a beneficiary or holder under him may be seriously injured by revocation of a credit thought to be irrevocable.

Furthermore, it is possible that the beneficiary will not learn of revocation of the credit he thought irrevocable until he presents his drafts to the bank, ${ }^{01}$ for Section 5-106(c) permits the issuer to modify or cancel a credit deemed

(1948). The Code also follows the general trend of contract law and makes the proceeds freely assignable. $\S 5-115(2)$. The comment to $\S 5-115$ indicates that what is meant by assignment of proceeds is assignment by the beneficiary of moncy claims that arise from the letter of credit. Compare this statement with the language of ICC Cusroms, art. 49, which refers confusingly to transfer of the credits and assignment of procecds. Yet it is doubtful if the Code does, or could do, much to clarify law and practice in the unsettled field. See Eriksson v. Refiners Export Co., 264 App. Div. 525, 35 N.Y.S.2d 829 (1st Dep't $1942)$; and McGowan, supra. Under the Code, banks may honor drafts drawn by bencficiary despite filing of notice of assignment of proceeds. Final Draft $\S 5-115(2)$. This provision, though, is sound, for businessmen will be discouraged from accepting assignments of proceeds unless the beneficiary is known to be honest. And the provision protects banks from the comparatively high probability of error that comes with filing separate but controlling papers. While Article 5 does a fine job in handlings the assignment and transfer situations, it fails to treat specifically a major development in the field of documentary credits: use of the letter of credit by the beneficiary as the basis for opening up a second letter. By means of this so-called "back-to-back" credit, the beneficiary is able to finance his operations. The typical situation finds the beneficiary as an exporter who must buy raw material or manufactured goods without too much ready capital. Armed with the first letter of credit, the exporter will try to arrange with a bank in his country to open a letter of credit in favor of his supplier. See Kingdom of Sweden v. New York Trust Co., 197 Misc. 431, 96 N.Y.S.2d 779 (Sup. Ct. 1949). The advantage of "back-to-back" credits and the dangers entailed in their use are discussed in WARD \& HARFIELD 140-5.

Not much litigation has yet developed regarding "back-to-back" credits, but one case has said that the two credits are independent, that it is immaterial that the customer knows or does not know of the existence of the second credit, and that the beneficiary is not transferring the prime credit. Kingdom of Sweden v. New York Trust Co., supra. It is submitted that the Code should have codified these rules.

59. See forms in Ward \& Harfiedd 165, 167-8, 170-1. For English forms, sce Davis 187-8; GuTTERIDGe 109-112. See also forms on file in Yale Law Library.

60. For the informality, lack of clear statements of revacability, and varicty of domestic and even some international credits, see, e.g., Drink-O-Matic, Inc., v. Franl, 141 F.2d 177, 179 n.1 (1944); Lafargue v. Hanison, 70 Cal. 380, 9 Pac. 259 (18s5); Russell Grader MIfg. Co. v. Farmers' Exchange Bank, 49 N.D. 999, 194 N.W. 387 (1923) ; Consolidated Sales Co. v. Bank of Hampton Roads, 193 Va. 307, 68 S.E.2d 652 (1952) ; Foglino v. Webster, 217 App. Div. 282, 216 N.Y. Supp. 225 (1st Dep't 1926); see also Bank of Italy v. Merchants' Nat. Bank, 197 App. Div. 150, 188 N.Y. Supp، 183 (4th Dep't 1921) ("guarantee"). The possiblity of ambiguity in the credit is on the increase as telegraphic credits in domestic credits become more popular.

61. See Cape Asbestos Co. v. Lloyds Bank, [1921] W.N. 474 (K.B.). 
revocable at "any moment" before payment. ${ }^{.2}$ Damages consequently could be substantial. Not only might a seller-beneficiary thus be damaged by" revocation after reliance, but the customer himself might be injured by a seller who takes advantage of an ambiguously worded notification to rescind performance on a contract calling for an irrevocable credit. ${ }^{03}$

Following some precedent ${ }^{04}$ and recognizing that revocable credits are rarely used in practice, ${ }^{65}$ earlier drafts of the Code ran the presumption in favor of irrevocability. ${ }^{60}$ Moreover, one draft made bank stipulations permit-

62. The section follows United States Steel Products Co. v. Irving Banl:-Columbia Trust Co., 9 F.2d 230 (2d Cir. 1925); Cape Asbestos Co. v. Llowds Banls, [1921] W..2. 474 (K.B.); accord. I.C.C. Custons, art. 4. But see D.wrs 31 Gurtessuse 34 (both quoting the judge in the Cape Ashestos case as recognizing, despite his decision, that notice is "reasonable and business-like").

63. See $\$ 2-325$ (1) (failure to set up proper credit is a breach of contrast).

64. American Steel Corp. v. Irving Nat. Bank, $260^{\circ}$ Fed. 41 (2d Cir. 1920); stc Foglino \& Co. v. Webster, 217 App. Div. 282, 296, 216 N.Y. Supp. 225, 237 (1st Dep't), modified as to damages, 244 N.Y. 516, 155 N.E. 878 (1926); but cf. First Wicconsin Nat. Bank v. Forsyth Letter Co., 1S9 Wis. 9, 206 N.W. 843 (1026) (circumstances of transaction and the general form of the credit, not merely the words, are controlling).

65. The rezocable credit is typically met by United States banks in only two forms -the so-called revocable "authority to purchase" and the "authority to pay." Under the authority to purchase, seller draws his drafts on the buyer. Invariably buyer's banl: will instruct its branch or a correspondent in beneficiary's country to advise beneficiary that the correspondent is authorized to purchase drafts. The correspondent, ltowever, clearly informs beneficiary that it may revoke its willingness to purchase without notice. Furthermore, recourse will be had against drawer should customer fail to honor. Thus the revocable authority to purchase is not a lank credit. Waro \& Hanfieno 10.

The revocable authority to pay operates along the same lines as the revosable authority to purchase, except that drafts are drawn on the correspondent banl: itself. Since correspondent is the drawce, it has no recourse against drawing bensficiary once it has paid but is not reimbursed. Not being a firm bank credit, the revocable authority to pay is rarely used, and then, for the most jart, only to cover the periud of shipment. INTERVIEWS. See WARD \& HARFIELD 10-11, 161-3.

Rezocable authorities to purchase must be distinguished from irreveable credits established by an issuer in which its branch or correspondent is authorized to purchase (irreciocable authorities to purchase). In the irrevocable authority it is understogd that the correspondent has no recourse against seller (drawer) and is not entitled to disecunt drafts, but must pay the face amount. These irrevocable authorities were once popular in the Far East trade. See Bank of East Asia v. Pang, 140 Wash. 603, 249 Pac. 10,0 (1926) ; 1949 Drafts $\$ 4106$, and comments; see also Ward, Bass Creurts arí Acceprances 30, 48 (2d ed. 1931 ).

Revocable authorities to pay should be distinguished from the irrevoeable credit issued by issuer which permits the beneficiary to draw drafts on corresrondent and which are payable at correspondent's bank (straight credit). Issuer is liable for revocation to the beneficiary in this situation. Correspondent bank is not. Still there will ba no right of recourse by correspondent should issuer dishonor when it presents. See furm in WaRd \& HARFIELD 67.

66. 1950 DRAFT $\$ 5-104 ; 1949$ Draft $\$ 4-105 ; 1946$ OeT. Draft $\$ 3 ; 1946$ FEd. DRAFT $\$ 3$. The 1951 draft contained the present presumption. 1951 Drars $\$$ 5-104(3). ICC Crstouss, art. 3 also states the presumption for revocability. 
ting revocation after the shipment of goods ineffective. ${ }^{07}$ These provisions of earlier drafts appear preferable. ${ }^{68}$ Although banks control the wording of letters of credit, the present provisions would protect them from their own want of clarity. And although good business practice would demand that notice of revocation be sent before beneficiary's performance, ${ }^{60}$ banks are relieved of this reasonable responsibility by the final draft.

"Clean" credits. The scope of the final draft of Article 5 was deliberately narrowed to exclude all reference to "clean" credits ${ }^{70}$-i.e. . letters of credit requiring presentation only of drafts unaccompanied by other documents. Although the infrequency of use of such credits may prevent this omission from representing too serious a defect in the Code, customers do occasionally obtain clean credits as a means of financing their beneficiary-sellers. ${ }^{71}$ In view of this practical utility of clean credits, there appears no substantial justification for their exclusion from the Code. ${ }^{72}$

67. $\S 5-106(2)(c)$.

68. See McLaughlin, The Letter of Credit Provisions of the Proposed Uniform Commercial Code, 63 HARv. L. Rev. 1373, 1380 (1950) (praising change made by 1950 DRAFT in rule allowing revocation at any time before payment).

An earlier draft argues for the presumption of irrevocability: "[C]redit in a bank's signed promise is a word intended to be relied on. The subsection [1949 DRAFT \& 4-104(2) ] therefore sets up a real burden for any issuer to lift, if he argucs 'credit' is not really intended to mean 'credit.' The issuers are the experts in the law who preparc the documents; they are the proper ones to pick up such a burden. It is a burden simple to lift." 1949 Draft 4-105, comment 2.

69. See note 62 supra.

70. See title adopted for Article 5 (Documentary Letters of Credit); $\$ 5-102$, comment 1.

Earlier drafts included clean credits within their scope: 1951 DrAFT $\$ 5-104(1)$ (b) ; 1950 Draft $\$ 5-104 ; 1949$ Draft $\$ 4-103$ (b). But the first two drafts did not include "clean" credits within their definition of "banker's commercial credits." 1946 Ocr. DRAFT $\S 1 ; 1946$ FEB. DRAFT $\$ 1$. It was contemplated that other sections would cover cleiul credits. 1946 Oct. Draft \& 1, comment.

71. See, e.g., American Nat. Bank \& Trust Co. v. Banco Nacional De Nicaragua, 231 Ala. 614, 166 So. 8 (1936); same, 238 Ala. 128, 189 So. 191 (1939).

'In the 'clean' credit the underlying transaction is most typically an agency to purchase, the beneficiary being the agent and being in a market where his purchases call for cash. .." 1949 DRAFT $\S 4-103$, comment 3. The reference is particularly to the socalled "red clauses" used to a great extent in undeveloped regions where the market is difficult to reach. See note 17 supra. The charges of the bank for clean credits are higher than on documentary credits, and the bank will more frequently reçuire the customer to put it in funds before opening the credit. InTERviEWs. See WARd \& HakeFIELD 132-6.

72. A possible ground for exclusion of clean credits is the difficulty in framing at definition which would exclude such non-commercial instruments as travellers' cleckss. But see 1951 Draft \& 5-104(1) (b). See also 1949 Draft \& 4-103, comment 3 (intent to cover "travellers' letters of credit"). For a comparison of travellers' letters of credit and commercial credits, see WiLus \& EDWARDS, BANKING AND Business 275-6 (2d ed. 1925). Travellers' clean credits are much more susceptible to fraud and forgery than commercial credits. See Pines v. United States, 123 F.2d 825 (8th Cir. 1942). Another 


\section{Documentary Complance}

\section{The Demand for Payment}

Whenever documentary drafts are offered, ${ }^{73}$ the issuer and its correspondent must decide whether or not they will honor. Following typical statements in existing case law, ${ }^{74}$ Section $5-107$ (1) of the proposed Code states the general proposition that "a documentary draft which meets the terms of the relevant irrevocable credit must be honored." The right to reject under this section comes by negative implication: when documentary drafts fail to meet the terms of the credit, they can be rejected, and the presenter then will have no action against the rejecting bank.

The "credit" apparently means simply the notification to the beneficiary. ${ }^{\text {To }}$ But the serious problem arises as to what the beneficiary must do "to meet the terms of the credit." As a practical matter, the question is one of determining how closely the documents must conform to the specifications of the notification form.

Strict or substantial compliance. ${ }^{70}$ The negative implication of Section 5107(1) could easily be interpreted as requiring a strict compliance rule in all cases. ${ }^{77}$ On the other hand, Section 5-102(2) permits reference in interpreting Article 5 to "uniform customs among banks."78 And in practice banks sometimes do relax the degree of conformity they require. Under the

possible ground was the difficulty of distinguishing the clean credit from tankers' remittances covered by Article 4. See 1949 DRATT \$ 4-103, comment 3.

73. In general, no distinction will be made, or is made in the Code, as to conformity of documents when presentation is by the beneficiary, authorized assignees, holders, holderbanks not authorized to pay under the credit (negotiating banks), or collecting banls (banks collecting for the account of another bank or person). But sse test on fraud and forgery, pages 252 et seq., infra, where distinctions are made for holders in due course.

74. See, e.g., O'Meara v. National Park Bank, 239 N.Y. 386, 396, 146 N.E. 636, 639 (1925) ; Sztejn v. Schroder Banking Corp., 177 Mfisc. 719, 722, 31 N.Y.S.2d 631, 634-5 (Sup. Ct. 1941).

75. See definition, Final Drafr $\S 5-103(1)$ (a). The case law requires only that the documents comply with the notification. E.g., Amerian Steel Co. v. Irving Nat. Bank, 266 Fed. 41, 44 (2d Cir. 1920), cert. denied, 258 U.S. 617 (1922); Doalger v. Battery Park Nat. Bank, 201 App. Div. 515, 194 N.Y. Supp. 923 (1st Dep't 1922).

76. The problem of strict or substantial compliance is discussed in Davis 124; WarD \& HaRfIELd 43 et seq.; Brown, Documeatary Conditions of Fayment is Commerial Letters of Credit. 13 Tulane L. Rev. 493 (1939); Finkelstein, Performantec of Conditions under a Letter of Credit. 25 CoL L. Rev. 724 (1925). See also MrLaughlin, The Letter of Credit Provisions of the Proposed ('niform Commercial Code, 63 Hnisv. L. REv. 1373, 1376 et. seq. (1950).

77. This is in accordance with the general propositions of the case law. E.g., Crodker First Nat. Bank v. De Sousa, 27 F.2d 462 (9th Cir.), cert. denied, 27S U.S. 650 (1923); Lamborn v. Lake Shore Banking \& Trust Co., 196 App. Div. 504, 188 N.Y. Supp. 162 (1st Dep't), aff'd, 231 N.Y. 616, 132 N.E. 911 (1921).

78. See $\$ 5-102(3)$ : "In construing this Article reference may be had to uniform customs among banks." Comment 4 to the Section refers to the general provisions for usage of trade appearing in $\$ 1-205$. Comment 4 then recognizes the existence of the ICC Custosss. However, it reads: "But the document in question [ICC Custouss] has not been submitted to the American Law Institute nor the Conference of Commissioners 
Code, therefore, the courts may be able to ascertain applicable standards of documentary compliance only by an extensive examination of industry practices.

Compliance of bills of lading.70 Analysis of banking customs reveals two important situations-both involving bills of lading-in which banks do not and should not require strict conformity of documents. The first arises when bills of lading do not contain an exact description of the goods as set out in the letter of credit. Bills of lading rarely will contain detailed clescriptions of the goods, since carriers refuse to inspect the goods or stubject themselves to liability by extensive representations..$^{80}$ Furthermore, the carrier does not as a rule see the letter of credit; and he cannot be expected to use technical terms. Consequently, in commercial practice, and in some of the case law, ${ }^{81}$ bills of lading are given a subordinate position in determining whether the terms of the credit have been met. ${ }^{82}$ The invoices-and, where required by the notification, inspection documents--m are made the key to conformity.

on Uniform State Laws, and they have of course not undertaken to consider, criticizc, or revise it, nor recommend it for enactment by reference or otherwise. . . [The ICC Customs] will of course enter into any contract between parties who adhere to it . . . and is undoubtedly excellent evidence of what banks and others concerned are expected to do in international transactions to which it relates. But the 'uniform customs amony banks' . . are those actually existing when the question arises, whether or not in accordance with the provisions of any particular formulation." Final Draft \& 5-102, comment 4.

79. When ocean transportation is involved, letters of credit generally call for an "on board" bill of lading-one stating that goods have actually been placed on board a ship. Because of the difficulty of designating ships in advance and the exigencies of modern commerce, however, "received-for-shipment" bills of lading and other variants are often substituted for the "on-board" bill when the credit calls for evidence of shipment or "ocean" bills of lading. For the difficulties arising see, Vietor v. National City Bank, 200 App. Div. 557, 193 N.Y. Supp. 868 (1st Dep't 1922) (letter of credit called for "ocean" bills of lading; reversible error not to hear evidence that N. Y. Bankcrs Commercial Credit Conference of 1920 and accepted practice considered a "receivect-forshipment bill" as proper delivery); WARD \& HARFIELD 36; Brown, supra note 76. Sece ICC Customs, art. 19. For the problems in air transport, see WARD \& Harfietd 41-2; Sneed, A Proposed Solution to the Documentary Problem of Airbornc International Trade, 65 HARv. L. REv. 1392 (1952).

80. See McLaughlin, supra note 76, at 1376; Border Nat. Bank v. American Nat. Bank, 282 Fed. 73 (5th Cir.), cert. denied, 260 U.S. 701 (1922). Sce also 1946 FLu. DrAFT § 14(3).

81. See Crocker First Nat. Bank v. De Sousa, 27 F.2d 462, 463 (9th Cir.), cert. denicd 278 U.S. 650 (1928) ; cf. Laudisi v. American Exchange Nat. Bank, 239 N.Y. 234, 146 N.E. 347 (1924) (reimbursement action); but cf. Lamborn v. Lake Shore Bank \& 'Trust Co., 196 App. Div. 504, 188 N.Y. Supp. 162 (1st Dep't), aff'd, 231 N.Y. 616, 132 N.E. 911 (1921) ; National City Bank v. Seattle Nat. Bank, 121 Wash. 416, 209 Pac. 705 (1022). Contra: Rayner \& Co. v. Hambro's Bank, Ltd. [1943] 1 K.B. 37 (C.A.). For suggestion that English courts may require a stricter rule of conformity than American courts, sec Megrah, Commercial Letters of Credit, 102 L.J. News 410 (1952).

82. I NTERviEws. But in connection with inland railroad shipments, shorthand bills of lading under the so-called "telegraphic guaranty" are frequently the only documents 
The second situation is presented when, as typically, the letter of credit calls for presentation of a "clean" bill of lading. . $^{3}$ The question is not usually posed as one of strict or substantial compliance but merely in terms of the legal conclusions of "clean" or "foul." A clean bill of lading is one which has nothing noted on it-as, for example, a statement that goods are damagedwhich qualifies its description of the shipment. ${ }^{84}$ Commercial practice has led courts to recognize, however, that all carrier notations do not "foul" the bill of lading in letters of credit transactions. ${ }^{\mathrm{T}}$ Federal ${ }^{80}$ and state ${ }^{8 \mathrm{i}}$ statutes validating carrier disclaimers have led carriers to print denials of linowledge of the condition of the merchandise or content of packages covered by their bills. And, often, written or stamped notations on the bills are merely disclaimers of knowledge rather than affirmative assertions that there is something wrong with the goods. In addition, many notations are such as to show at most a possibility that the goods may arrive in poor condition. ${ }^{89}$ Thus. commentators have recognized that a rule which would render bills of lading foul, because they contained customary disclaimers or implied the existence of possible defects on arrival, would be at odds with commercial reality. ${ }^{83}$

One earlier draft of Article 5 met the problem of inesact descriptions in the bills of lading head-on. It codified distinctly the working rule: when the bills of lading did not conflict with descriptions in complying invoices or other documents, inexactness was excused..$^{00}$ Conditions which the credit notification

required. In such cases strict compliance should be required. See Continental Nat. Bant: v. Tremont Trust Co, 4 F.2d 219 (1st Cir. 1925) ; Bank of Italy v. Mferchant's Nat. Bank, 236 N.Y. 106, 140 N.E. 211 (1923).

83. For an excellent discussion of clean bills of lading, see Draper, What Is a "Clean" Blil of Lading?-A Problem in Finaning Intcrnational Trade, 37 Consen L.Q. 56 (1951). See also Brown, sitpra note 76, at 499; Camp v. Corn Exchange Nat. Banls, $285 \mathrm{~Pa} 337,132$ Atl. 189 (1926).

84. "A clean shipping document is one which hears no superimposcd clauses expressly declaring a defective condition of the goods or paclaging." ICC Cusro:ss, art 18. See also 2 Whiliston, Sales $\$ 405 c$ (rev. ed. 194\$); Draper, surru note 83.

85. See Camp v. Corn Exchange Nat. Fank, 2N5 Pa. 337, 132 Atl. 189 (1926) (evidence of customary practices admitted to show what was a "clean" hill of lading). See also ICC Custons, art. 18.

86. 39 STAт. 541 (1916), 49 U.S.C. \$ 101 (1946). Sce Draper, sufra nute 83, at 61 ; Note, Limitations of Carricr's Liability and the Confict of Lais', 54 HArs. L. Rov. 64.3 (1941).

87. Undforer Bmls of Lading Act $\$ 23$ et siq. For Code provisions, see Fu:al DRAFT, art 7.

QS. Among the typical notations are: "used drums," "disculurcd," "second-hand cases," "container second-hand lumber."

89. See Draper, supra note 83, at 62-3; and alsu, Camp v. Corn Exchange Nat. Bank, 285 Pa. 337, 345, 132 Atl. 189, 191 (1926).

90. 1946 FEB. DRAFT $\$ 17(3)$ ("Unless otherwise agreed, the decriptiun may la contained in any one of the documents which are tendered"). (f. Richard v. Royal Banl: of Canada, 23 F.2d 430 (2d Cir. 1928) ; Laudisi v. American Exchange Nat. Eanl;, 23"s N.Y. 234, 146 N.E. 317 (1924). See also 1950 DRuFT $\$ 5-11 \$(21(a) ; 1944$ UL1F $+11+(2)(a)$. 
did not expressly require to be evidenced by the bills of lading, or other third party documents, were to be satisfied when compliance was indicated in the invoice or in an accompanying statement of the beneficiary. ${ }^{01}$ The bills of lading were thus reduced to their proper role as mere documents of title. ${ }^{02}$

No draft of the Code, however, has attempted to detail rules for handling clean bills of lading. The Customs and Practices of the International Chanber of Commerce allows issuers to refuse bills of lading bearing any reservations as to apparent condition of goods and packaging. ${ }^{03}$ The same privilege is perhaps given by Article 5's vague reference to "banking customs." St Still such discretion ignores the position of the beneficiary who may be injured by rejection. A far better rule would state that unless the bills of lading affirmatively show a defect in the goods or packaging, documentary clrafts complying with all the other terms of the credit must be honorecl.

Compliance of other documents. Apart from these commercially necessary exceptions for bills of lading, issuing banks should have the right to demand strict compliance with the terms of the notification before payment to the holder. ${ }^{.5}$ Discrepancies as to the number, character, or terms of other documents, ${ }^{96}$ such as third party inspection papers ${ }^{97}$ and insurance forms, should justify refusal to pay. But if the codifiers had desired to permit banking practice to modify the rule, they should have made those exceptions explicit,

91. 1946 FEB. DRAFT $\S 14(2)$. This is the rationale behind Laudisi v. American Nat. Bank, 239 N.Y. 234, 146 N.E. 347 (1924) (credit called for "Alicinte Bouchez grapse"; bill of lading read merely "grapes," but compliance indicated in the invoices). See also Bank of America v. Whitney-Central Nat. Bank, 291 Fed. 929 (5th Cir. 1923), pet. dismissed, 264 U.S. 598 (1924) (reimbursement action: mere transposition of adjectives does not excuse bank).

Compare ICC Custors, art. 33 ("The description of the goods in the Commercial Invoice must correspond with the description in the credit. Wherever the goods are described in the remaining documents, description in general terms will be acceptable"), with 1951 DrafT $\$ 5-119$ (2) ("Any condition . . . not required to be evidenced by a third party document can be fulfilled by an appropriate statement of the beneficiary in the invoice provided such statement is not inconsistent with any accompanying third party document").

92. McLaughlin, supra note 76 , at $\mathbf{1 3 7 6 - 7 .}$

93. ICC Customs, art. 9.

94. § 5-102(3).

95. An additional relaxation of the strict compliance requirement may also be justified where the document of title offered is one superior to the one called for in the letter of credit, e.g., a bill of lading instead of a forwarding agent's receipt. But sce the rule and rationale in an English case, National Bank of South Africa v. Banca Italiana di Sconto, 10 Ll. L. Rep. 531 (C.A. 1922).

96. Third party documents most frequently required are weighing certificates, customs clearance receipts, consular invoices, and certificates of quality from chambers of commerce or experts. See Brown, supra note 76, at 497 ; and ICC CusToms, art. 34.

97. Inspection papers are the customer's and issuer's security that the goods arc shipped as represented; thus it is of great important that these papers when asked for should strictly conform to the terms of the bargain. See Manatee County State Bank v. 
as did earlier drafts.98 Departure from administratively simple standards invites litigation of the most expensive type. A troubling case in the Second Circuit, Dixon, Irmaos \& Cia. v. Chase National Bank, illustrates the point graphically.99 The beneficiary's collecting bank had presented a documentary draft under a letter of credit accompanied by an incomplete set of bills of lading. Despite the presenter's offer to indemnify the issuer for any loss it might suffer by acceptance, the issuer refused to honor. On suit by the beneficiary, the parties introduced high-salaried bank executives to testify concerning the existence of a custom of accepting such indemnities from "prime" New Yorl: banks in lieu of a full set of bills of lading. In finding for the beneficiary, the Second Circuit ignored precedent ${ }^{101}$ and accepted the position that the term "full set" could be interpreted by proof of banking practices. ${ }^{102}$ is a result, bankers have since been concerned over the extent to which courts may hold them to practices once thought discretionary. ${ }^{103}$

Weatherly, 144 Ala $655,658-9$; 39 So. 988,989 (1005). The same rule of strict conformity should also apply where the carrier is required to certify the bill of lading.

See 1946 FEB. DRAFT $\$$ 14(2) :

"Shipping and insurance documents, consular invoices, certificates of weight, inspection or the like, must with respect to all matters properly evidenced by such documents, comply strictly with the terms of the credit. But with respeet to matters not currently available for certification by third party documents the seller's invoice is sufficient.

"Other terms and conditions of the credit such as those of time, amount and the like, must be strictly complied with."

98. Earlier drafts, for example, codified the rule that in overseas shipments any part of the bill of lading is sufficient if accompanied by an indemnity. 1951 DRAFr

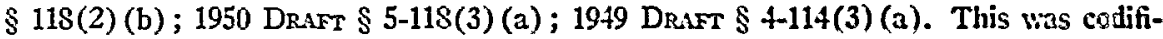
cation of the practice of New York banks, which facilitates the flow of goods. However, the practice in New York is confined to "prime" banks inter sese and purhaps is not the general practice over the country. Assuming, however, the practice is desirable, the Code should have stated the rule and avoided litigation. See notes 99-104 infra.

99. 144 F.2d 759 (2d Cir.), cert. donicd, 324 U.S. $\$ 50$ (1944). For a diceussiun of the case, see Backus \& Farfield, Custonn and Letters of Credit: The Dixon, Irmaos Cose, 52 COL. L. REv. 589 (1952).

100. A model indemnification agreement reads as follows: "In consideration of your paying (accepting) the above described draft, we agree to pay to you forr the account of yourself and of the customer for whose account you have issued the . . . credit, as interest may appear, such amount as will hold you and such customer harmless fröm all consequences which may arise from the following discrepancies. . . Cousurste Uniforitity in Docunients \& Practices of the Bankers Assucintion fur Fonele: TRADE, ETGHTH INTERNI REPORT (Oct. 5, 1945).

101. See Anglo-South American Trust Co. v. Uhe, 201 N.Y. 150, 1\&4 N.E. 741 (1933) ; Kronman \& Co. v. Public Nat. Bank, $21 S$ App. Div. 624, 218 N.Y. Supp. 616 (1st Dep't 1926) ; Rayner \& Co. v. Hambros Bank, [1943] 1 K. 37 (C.A. 1942); Scott \& Co. v. Barclays Bank, [1923] 2 K.B. 1.

102. "In our opinion the custom under consideration explains the meaning of the technical phrase 'full set of bills of lading' and is incorporated by implication into the terms of the defendant's letter of credit." Dixon, Irmaos \& Cia v. Chase Nat. Banl;, 144 F.2d 759, 762 (1944).

103. Interviews. See also Ward \& HaRfiend 4S-9; Bachus \& Harfield, sufra nut 99, at 59; Dixon, Irmaos \& Cia. v. Chase Nat. Bank, 144 F.2d 759 (2d Cir. 1944), 
The present draft of Article 5 does nothing to clarify the obligations of banks or rights of presenters when documents are offered for payment. Although earlier drafts pointed to a relatively simple and workable method of defining proper standards for documentary compliance, the present Code falls far short of that goal. Instead of eliminating problems, its imprecise reference to "uniform banking customs"104 may lead the parties into a maze of litigation.

\section{Reimbursement}

The right of the issuer of a documentary letter of credit to reimbursement from the customer depends, at common law, upon the issuer's fulfillment of his own obligations under the contract between the two parties. ${ }^{105}$ By such a contract, the customer undertakes to reimburse the issuer for payments on documentary drafts which comply with the specifications of that contract. ${ }^{100}$ But the standards for judging compliance are somewhat unsettled. Courts seem to apply a less stringent standard of compliance in reimbursement cases than in demand-for-payment cases. ${ }^{107}$

reversing 53 F. Supp. 933 (S.D.N.Y. 1943), cert. denied, 324 U.S. 850 (1944). The present version of the Code says merely that a bank seeking honor, negotiation, or reimbursement may give indemnities. FINAL DRAFT $\$ 5-113$. This guards against the possibility of a claim that the bank was acting ultra vires. Id. at comment. See note 24 supra.

Earlier drafts seemed to have codified the Dixon, Irmaos rule on indemnities, 1951 Draft $\S 5-118(2) ; 1950$ Draft $\S 5-118$ (3) (a). See also 1951 DrafT $\$ \S 5-123(1)$, (2); 1950 DRAFT \& 5-123; 1946 Oct. DraFT \& 16 (indemnity agreement inuring to the benefit of subsequent takers).

104. See note 78 supra.

105. See, e.g., Crocker First Nat. Bank v. De Sousa, 27 F.2d (9th Cir. 1928) ; Camp v. Corn Exchange Nat. Bank, $285 \mathrm{~Pa} .337,132$ Atl. 189 (1926). Frequently, this is lost sight of in the dicta of courts. As a result there is a tendency to speak of the bank's right to reimbursement against the buyer in terms of the necessity of the bank paying holders of drafts under the credit. See Pan-American Bank \& Trust Co. v. National City Bank, 6 F.2d 762, 769 (2d Cir.), cert. denied, 269 U.S. 554 (1925), and Finkkestein 149 n.9. But as Mr. Finkelstein concludes:

"The problem [of reimbursement] can be settled only by considering the relations between the buyer and the bank, as distinct from those between the seller and the bank." FINKELSTEIN 149.

The contract between the issuer and customer is normally viewed as an agrcement to indemnify and the banker must meet the terms of this contract- "letter of request" as the forms used are called-if he expects to be reimbursed. DAvIs 46 ct scq.

106. See, e.g., Anglo-South Amẹrican Trust Co. v. Uhe, 281 N.Y. 150, 184 N.E. 471 (1933).

107. Compare, e.g., First Nat. Bank of Lacon v. Bensley, 2 Fed. 609 (C.C.N.D. Ill. 1880); Manatee County State Bank v. Weatherly, 144 Ala. 655, 39 So. 988 (1905); Moss v. Old Colony Trust Co., 246 Mass. 139, 140 N.E. 803 (1923) (strict compliance for payment), with Richard v. Royal Bank of Canada, 23 F.2d 430 (2d Cir. 1928); Bunk of New York v. Atterbury Bros., 226 App. Div. 117, 254 N.Y. Supp. 442 (1929), aff'l, 253 N.Y. 568, 171 N.E. 786 (1930) (more liberal rule for reimbursement). 
The Code does nothing to clarify the case law. Instead, it may introduce new problems. Section 5-107(2) states that when payment is "duly male under the credit," an issuer or other paying bank is entitled to reimbursement. ${ }^{111}$ And under Section 5-107(3), the "issuer's obligation to its customer includes observance of customary banking practices."1w9 Certainly such standards will allow reimbursement in any case where an issuer can le forced by the Code to honor documentary dratts. But problems may arise when an issuer honors drafts which in fact he is not compulled to honor. Earlier drafts stated a "substantial" compliance rule: the customer hal to reimburse if, under his underlying sales contract with the seller, he wuld have had to accept the documents. ${ }^{111}$ Now .Article 5, however, leaves open whether strict compliance or substantial compliance shall be required. "Payment duly made" might encompass either rule. MIorewer, the provision calling for observance of "customary banking practices" may stimulate litigation in reimbursement situations. One practice among large isuers, for example, is to contact the customer and ask pernission to honor documents observed to contain discrepancies. ${ }^{111}$ Should this lie treated as a "custom" within Section 5-107(3), failure to seek such permission might lead to a denial of reimbursement even where ducuments "substantially complied."

108. "Unless otherwise agreed an issuing, paying, negotiating or accepting banl iv entitled to immediate reimbursement of any payment duly made under the crodit and to be put in effectively available funds no later than the day before maturity of any acceptance duly made under the credit." Fin,LL Drifr \$ 5-107(2) (emphasis added).

The Code seems to carry over the confusion of some dicta in stuveral cases. See note 105 supra.

109. That this language may have something to do with the problem of the customer's rights to reject non-complying documents is perhaps not initially anjarcnt. But comment 4 to $\$ 5-107(3)$ reads: "Under this subsection, the issuer and its custumer may agree upon standards to measure the issuer's performance." The banks in international trade usually protect themselves by setting out standards for themselves. Euried deep in the recesses of the printed matter on the requesting forms is usually a clause reading something like this:

"[W]e agree that any action by you or by any correspondent of yuurs under or in connection with the Credit or the relative drafts, documents or property talien or omitted in good faith on behalf of or for the protection of either you or us, shall be binding on us and shall not put you or your correspondunt under any resulting liability to us; and we agree, except as may otherwise be provided herein, to hold you and your correspondent indemnified and harmless against any liability and to reimburse you upon demand for any loss or expense including reasonable attorneys' fees, arising in conncetion with the Credit." Application Form of the Corn Exehange Trust Company of New Yurl, cl. 9. See Fixal DRAFT $\$ 107(3)$, comment 4 ("Thuse agreuments will ba cuntrolling unless manifestly unreasonable in disclaiming gord faith, or rcasonable care").

110. See 1951 Draft $\$ 5-123(2)$ : "An issuer or autharized correspondent who in good faith honors documents which are non-complying (a) has a right of rimbursement against its customer if the documents are such as the customer vuuld lo ubligated to accept under his underlying contract." Accord: 1950 DRAFr \$ 5-123; 1949 DRarr $\$ 4-$ 122(1).

111. INTERTIEWS. 
Article 5's lack of precision and abdication to inarticulated practices in defining the performance required of the issuer seem entirely unsatisfactory. ${ }^{112}$ Should a clearly defined "strict compliance" test be applied when documents are presented for payment, such an administratively simple device should also be applied in reimbursement actions. ${ }^{113}$ In fact, a similar practice is now followed by leading New York banks, which do not attempt to obtain reimbursement when a customer is unwilling to accept documents containing defects. ${ }^{114}$ Exceptions to a strict compliance rule, if desired, should have been clearly noted.

\section{The Letter of Credit Transaction, the Underlying Sales Trans- ACtion, AND THE QUaLity OF THE Goods}

\section{Conformity of Goods to Sales Contract}

The sales transaction between the buyer and seller gives rise to the letter of credit. But, under the case law, the issuing bank's duty to honor drafts drawn by the beneficiary and the customer's obligation to reimburse the issuer are not controlled by the underlying sales contract. ${ }^{116}$ This doctrine is codified

112. Compare the suggested presumptions in earlier drafts: for docuntents satisfying credit terms in 1951 DRAFT $\$ 5-118 ; 1950$ DRAFT $\$ 5-118$; for duration and expiration of the credits in 1951 DRAFT $\$ 5-114 ; 1950$ DRAFT $\$ 5-114$. See also ICC Customs, arts. 15-34 (documents), 35-48 (interpretation of terms). Codification in such detail as the ICC Custons would, perhaps, have been unwarranted. Practices within the United States vary greatly. And room for some change may be imperative in a statute difficult to amend. But the provisions of the earlier drafts seemed to have struck a discriminatinter balance. See McLaughlin, supra note 76 , at 1376 .

113. Commentators sometimes suggest that banks should have a broader right to demand reimbursement than the presenter has to demand payment. The suggestion is based on the reasoning that a bank is unacquainted with commercial terms; consequently it has no grounds to know when discrepancies are material when asked to pay. So when it does pay, it should be entitled to reimbursement so long as the customer suffers no actual damage. See Finkelstein 194-5; 1946 Feb. DRAFT 17-18; (comment to $\$ 20$ which laid down a substantial performance doctrine); Brown, supra note 76, at 505; see also cases cited, note 107 supra.

It is submitted, however, that the rule allowing reimbursement only for strict conformity where the bank can require it (leeway allowable on the documents of title) would accord better with the aim of skirting litigation. The leading American banks and their correspondents almost invariably ask their customers whether they should pay once discrepancies in the documents have been noted. INTERvIEws. This practice, which avoids litigation, would be encouraged under a general rule of strict compliance. For if customer consents, he will have waived his right to demand strict compliance from the bank. See Williams Ice Cream Co. v. Chase Nat. Bank, 120 Misc. 301, 306, 199 N.Y. Supp. 314, 318 (Sup. Ct. 1923), rev'd, 210 App. Div. 179, 205 N. Y. Supp. 446 (1st Dep't 1924).

114. INTERVIEWS.

115. E.g., American Steel Co. v. Irving Nat. Bank, 266 Fed. 41, 43 (2d Cir. 1920), reheard, 277 Fed. 1016 (2d Cir. 1921), cert denicd, 258 U.S. 617 (1922); Jones \& Co. v. Bend, 191 Cal. 551, 555, 217 Pac. 725, 727 (1923). 
in Section 5-111(1) of the Code. Under that provision, an issuer (or confirming bank) "is not excused from honor or reimbursement by the fact that the goods or documents do not conform to the underlying contract for sale," unless the bank contracts to the contrary. Moreover, the "scope" section of Article 5 declares that the Article as a whole "does not have relation to goods." 116

By decreasing the potential liability of the issuer and minimizing the time required to handle letter of credit transactions, absolution of issuers from any responsibility for non-conformity of goods to the underlying sales contract reduces the cost of letters of credit. ${ }^{117}$ And from the seller's viewpoint, refusal to allow issuers to dishonor drafts drawn against non-conforming goods is highly desirable. Prompt payment without dispute is often one of the seller's chief reasons for seeking a letter of credit.118 Should the goods in fact be non-conforming or defective, the seller would still be subject to suit by the buyer on the sales contract.

Adoption by the Code of the common-law rule that non-conformity of the goods to the sales contract is no defense in either payment or reimbursement actions thus appears justified. Even if such a defense were allowed against beneficiaries, it would have to be denied against holders in due course of documentary drafts, or the usefulness of such instruments would be seriously impaired. ${ }^{119}$ And presentation by such holders (banks) is the most common practice. Nor does the absence of the right to demand conformity of goods before payment prejudice the customer. He can easily obtain analogous protection by providing in the letter of credit that third-party inspection documents (certifying that the goods comply with the sales contract) be included among the required documents.

\section{Validity of Documents}

Should the maker's signature on a draft presented under a letter of credit be forged, the issuing bank would have a right to refuse payment or to recover payments from any holder other than one in due course. ${ }^{120}$ And the

116. Final DRaft $\$ 5-102(1)$. The rights and duties of buyer and seller in regard to the establishment of the credit as a condition of their sales contract are covered in Article 2, the Code's substitution for the Uniform Sales Act. Frinal Drart § 2-325.

117. Interviews. See Wakd \& Harfield 34. And see note 28 supro.

118. See, e.g., O’Meara v. National Park Bank, 239 N.Y. 386, 397, 146 N.E. 636, 639 (1925).

119. See Thayer, Irrezocable Credits in Isternational Connncre: Thcir Leyal Effects, 37 COL. L. Rev. 1326, 1343 (1937).

120. Honor would not be required since the drait would not mect the terms of the credit within the meaning of $\$ 5-107$. But the bank could not recorer from a holder in due course once payment had been made to him. Fra.u. DruFt $\$ \S 3-418,3-417$ (1). Sce also Price v. Neal, 4 Burr. 1335, 97 Eng. Rep. $\$ 71$ (1761), and cases under $\S 62$ of the Uniform Negotiable Instruments Law; Yinkelstal 236 n.33. 
customer would probably be entitled to protection against the issuer. ${ }^{120 a}$ Following case law and typical contracts used in international trade, however, the Corle places neither an issuing nor a confirming bank under any duty to probe beyond the face of the instruments to ascertain the genuineness of documcnts accompanying a draft under the terms of a letter of credit. ${ }^{121}$ So long as such documents are examined with care to determine that they are regular on their face, the issuer is entitled to reimbursement. ${ }^{\mathbf{1 2 2}}$

The Code does little to set out clear rules governing other aspects of validity of documents. They can be spun out, if at all, only indirectly. Under Section 5-111(2), an issuing or confirming bank may pay even a beneficiary on drafts regular on their face, even though it is notified by the customer of "forgery or fraud in a . . . document." But in such a situation the customer can obtain an injunction under Section 5-111(1) restraining the bank from paying anyone other than a holder in due course of the documentary draft. ${ }^{19 a}$ Reading both sections together, it would seem that the issuer has an option

120a. The common law would hold against the issuer should he charge his customer on drafts upon which the beneficiary's signature had been forged. And in fact the customer had a right to recover payments made to the issuer. British Linen Co, v. Wilson. 4 L.T.N.S. 162 (1861). But the Code is unclear as to whether or not an issucr could charge funds deposited by a customer or obtain reimbursement when it has actually paid on a forged draft. Under $\$ 5-107$, the right of reimbursement is given for a payment "duly made" under the credit. But under $\$ 5-111$, the fact that documents accompanying a draft are forged apparently does not contravene the "payment duly made" requirement. Since there is no reason for the bank necessarily to know the drawer's truc signature, it is possible that courts might not apply the full Price $v$. Neal doctrine to a forged draft. Instead, by analogy to $\S 5-111$, the courts might permit reimbursement when paymett is made in good faith upon the instrument. The right to reimbursement when the issuer has not been furnished with specimen signatures was clearly set out in 1946 FEV. DMAFT $\S 21(\mathrm{~b})$.

121. §5-110(1). This also applies to any bank called upon to pay or accept under a letter of credit. See, e.g., Havemeyer \& Co. v. Exchange National Bank, 293 Fed. 311 (8th Cir. 1923) ; Bank of New York \& Trust Co. v. Atterbury Bros., 226 App. Div. 117, 234 N.Y. Supp. 442 (1st Dep't 1929), aff'd, 253 N.Y. 569, 171 N.E. 786 (1930). Furthermore the issuer and a correspondent make no warranties as to the documents except as to their good faith. FINAL DRAFT $\$ 5-110(2)$.

The limited responsibility of $\S \S 5-110(1),(2)$ is that which is written into the requesting forms regularly used in international trade. WARD \& HARFLELD 182. Compare substantially the same provisions in ICC CusToms, arts. 9, 11.

122. The result is achieved by reading $\$ 5-110$ with $\$ 5-107(2)$ (reimbursement). This codifies the common law rule that if the bank pays without knowledge of fratud or forgery and there is no evidence on the face of the documents to suggest that they are not in order, then the bank is entitled to reimbursement. See, c.g., Havemeyer \& $\mathrm{Co}$. v. Exchange Nat. Bank, 293 Fed. 311 (8th Cir. 1923).

123. "[A] Court of appropriate jurisdiction may enjoin the issuing or confirming bank from honoring or reimbursing unless such honor or reimbursement is demanded by a paying, accepting, or confirming bank which has acted in good faith in reliance on the forged or fraudulent document or by a negotiating bank or other endorsee of a draft which is a holder in due course. . ." Final DRAFT \& 5-111(1). 
to refuse to pay and set up its defense of fraud or forgery ayainst any presenter except a holder in due course. ${ }^{124}$ But the issuer is in no case denied reimbursement when it does pay in the absence of an injunction stecured by the customer. ${ }^{12-5}$ The present draft's indirection may be compared to sume earlier draits which positively stated the issuer's right to set up fraud and forgery. 120

The major dificulty with the Code treatment, however, is its failure to set up criteria for "fraud in a . . . document." Such criteria would help to settle the problem of what evidence might be introduced or would be sufficient to support an inference of fraud when a customer seeks an injunction. ${ }^{127}$. Ind they would also help to clarify the extent to which the issuer may go beyond the documents to set up his defense of fraud.

As the Code now reads, "fraud in a .. . document" is likely to cunfuse rather than aid the courts. It would probably cover the situation where ducuments are fraudulently procured. ${ }^{129}$ But how far beyond this situation the provision would go is unclear. Case law suggests that drastic non-conformity of goods. such as rags for hemp, ${ }^{130}$ may in itself constitute prima facie evidence of fraud. At the other extreme, minor discrepancies such as would amount merely to a breach of warranty-absent a showing of deliberate misrepre-

124. This would follow the case law. See Sztejn v. Schroder Banling Curg. 17r Misc. 719, 721, 31 X.Y.S.2d $631635-6$ (Sup. Ct. 1942). See also Old Culony Trust Cu. r. Lawyers' Title \& Trust Co., 297 Fed. 152 (2d Cir.), cort. dented, 2 is U.S. 585 (1624).

125. "[T] a failure of title to a required document or to the insurance and is alse excuscd as against a seller or other consignor by a non-conformity of the goods su screre that it amounts to fraud." 1950 DRAFT $\$ 5-120$. See also 1949 DRirTs $\$ 4-116$.

126. See 1950 Draft $\$ 5-120 ; 19.4$ Drafr $\$ 4-116$.

127. The injunction sought will usually be a permanent injunction, but on props $r$ showing of possible irreparable loss an injunction pondente lite will be grantcd.

For typical demands, see Williams Ice Cream Co. v. Chase Nat. Banl, 210 Apr. Liv. 179, 205 N.Y. Supp. 446 (1st Dep't 1924); Sztejn v. Schroder Banking Corp., 177 Mise. 719, 31 N.Y.S.2d 631 (Sup. Ct. 1941) ; Grob v. Manujacturers Trust Co. 177 Mise. 45, 29 N.Y.S.2d 916 (Sup. Ct. 1941) ; Higgins v. Steinhardter, 106 Jfise. 16S, 175 N.X. Supp. 279 (Sup. Ct. 1919).

See also Frey \& Son, Inc, v. Sherburne Co., 196 Afp. Dix. \$49, 184 N.Y. Supp. 631 (1st Dep't 1920) (attempted permanent injunction against negetiation and fayment to third parties as well as against payment to the beneficiary).

123. Sce problem raised in regard to non-fraudulent discrepancies in U:Meara $v$ Nat. Park Bank, 239 N.Y. 326,146 N.E. 636 (1925).

129. See Bank of Tawain v. Union Nat. Bank, 1 F.2. 65 , 60-7 (3d Cir. 1924) (deliberate falsification, or knowledge of falsification, of date of transfurtation cusld be fraud in the documents); Williams Ice Cream Co. v. Chase Nat. Bank, 210 Agp. In: 179, 183, 205 N.Y. Supp. 446, 449 (1st Dep't 1924) (alteration of documents could b: fraud). And see Grob v. Manufacturers' Trust Co., 177 Mizc 45, 46, 2y X.Y.S.2d 916, 917 (Sup. Ct. 1941) ("If there were ... collusion between sellers . . . and issuers of bills of lading," injunction might possibly be granted).

130. Bank of Montreal v. Rechnagel, 109 N.Y. 422,17 N.E 217 (1:ss) (rago ior hemp); Sztejn v. Schroder Eanking Corp., 177 Misc. 719, 31 N.Y.S.3d u31 (Sup. Ct. 1941) (cowhair and rubbish for bristies). 
sentation-do not constitute fraud. ${ }^{131}$ Earlier drafts of the Code suggested that non-conformity of goods which "amounted to fraud"132 or "a failure of consideration"133 might be sufficient to establish "fraud in the documents" as a defense to issuer's payment. The elimination of those provisions from the present draft, however, leaves the issue in doubt.

Should the courts interpret "fraud in the documents" to include gross non-conformity of goods, they would be letting into the letter of credit transaction by the back door problems relating to the quality of the goods-not only in the injunction situation, but also in cases of issuer's defense against beneficiaries or holders not in due course. ${ }^{134}$ But under the circumstances the result may be reasonable. Since the bank would in no case be required to look beyond the face amount of documents even after notice from its customer, it rarely would indulge in inquiry as to fraud and risk litigating the issue. ${ }^{\text {t3o }}$ As a rule, then, the customer himself would bear the burden of proving to a court-in a suit for temporary or permanent injunction-such extreme non-conformity as would amount to fraud. Most often, non-conformity would be all he could show since the beneficiary would probably be in a foreign country. To cut the customer off completely from this offer of proof would be unjust. Furthermore, there is little reason to protect the seller's expectation of prompt and litigation-free payment where his actions can satisfy a court that fraud exists and an injunction should be ordered.

\section{RECOVERY OF DAMAGES FROM ISSUER}

An issuer's failure to perform his contract with a customer may injure both the customer and the beneficiary. ${ }^{136}$ In both cases the injured party should be entitled to recover from the issuer for his loss. The recovery problems under the Code differ depending upon whether the suit against the issuer is by the customer or by the beneficiary.

\section{Customer v. Issuer}

A customer may be injured if the issuer improperly refuses to honor drafts. wrongfully repudiates the whole transaction, or honors without obtaining necessary compliance. Although in the last situation the customer apparently

131. See Sztejn v. Schroder Banking Corp., 177 Misc. 719, 722, 31 N.Y.S. 2d 631, 634 (Sup. Ct. 1941). See also O'Meara v. National Park Bank, 239 N.Y. 386, 146 N.1E. 636 (1925).

132. 1950 DRAFT \& 5-120.

133. 1949 Draft \& 4-116.

134. Since the right to refuse comes from the permissive features of $\S 5-111(2)$ 's right to honor despite notice, the language of "fraud in a document" in that section apparently carries over as a defense for issuer. See note 123 supra.

135. But see the criticism of McLaughlin, stipra note 76, at 1378 .

136. See Kronman v. Public Nat. Bank, 218 App. Div. 624, 218 N.Y. Supp. 616 (1st Dep't 1926). 
may refuse to accept the documents and may deny reimbursement to the issuer, ${ }^{137}$ in no case does the Code state a damage remedy to compensate the customer for the contract breach involved. So if the customer is to be made whole, he will apparently have to recover on ordinary contract principles. ${ }^{138}$

Similarly, a customer may be injured by actions of the isster's correspondent. The Code declares that an advising bank must state the terms of the credit correctly. ${ }^{139}$ Perhaps this provision gives a customer the right to recover damages against the correspondent for inaccurate notification.140 But should that correspondent be a paying or confirming bank, the Code states no right of action for wrongful repudiation or dishonor. A customer who has not dealt directly with the correspondent bank may then find it impossible to recover damages directly from such correspondent because he lacks privity of contract.141

Moreover, in stating that the issuer has "no responsibility for any acts or omissions of the beneficiary or any other person," Section 5-107(3) of the Code $^{142}$ appears to relieve the issuer of liability for any acts of a corres-

137. $\S 5-107(2)$.

138. It may be noted also that no measure of damages or rules for the issuer is given when the beneficiary refuses to reimburse and accept documents. For an action on reimbursement, see Beneke v. Hoebler, 38 App. Div. 344, 58 N.Y. Supp. 16 (1st Dep't 1899), aff'd, 166 N.Y. 63160 N.E. 1107 (1901) (mitigation by resale not rcquired, since the bank does not have to "realize" on its collateral).

139. \$ 5-108. Contra: Scanlon v. First Nat. Fank, 249 N.Y. 9, 162 N.E. 567 (1923) (no duty to beneficiary to import any information).

140. The Code establishes liability for an advising lank "for the accuracy of its oun statement only." FINAL DRAFT \$ 5-108. This liability can be interireted to muan liability to the customer as well as to the beneficiary. Passibly, this effects a change in the law for New York. See Oelbermann v. National City Eank, 79 F.2d 524 (2d Cir. 1935): Kunlig Jarnvagsstyrelsen v. National City Bank, 20 F.2d 307 (2d Cir. 1927). Iiut in seeking to hold a foreign correspondent where the Code would not be applieable, the customer might not recover because of lack of privity of contract. Cf. Calico Printers" Ass'n v. Barclays Bank, Ltd, 36 Com. Cas. 197 (C..A. 1931) (no responsibility for negligently reporting on the quality of the goods). But sce $\$ 1-105$ (2) (a) (the Code will be applied if offer or acceptance is made in the jurisdiction in which it has bsen enacted). Still the liability of the correspondent even for cases under the Code is limited to the statcment, unless the correspondent specifically accepts liability for uther activity.

141. Kronman v. Public Nat. Bank, 218 App. Div. 624, 218 N.Y. Supp. gle (ist Dep't 1926) ; Equitable Trust Co. of New York v. Dawsin Yartners, Ltd., 25 Ll. L. Rep. 90 (C.A.), aff'd, 27 L1. L. Rep. 49 (H.L. 1926); Calico Printers Assin v. Barelays Bank, Ltd, 36 Com. Cas. 197 (C.A. 1931) ; cf. Oelbermann v. National City Eanl: of New York, 79 F.2d 534 (1935); Kunlig Jarnvagestyrelsen v. National City Lank, 20 F.2d 307 (1927); Courteen Seed Co. v. Hongkong \& Shanghai Banking Corp. 245 X.Y. 277,157 N.E. 272 (1935).

142. ICC Custons, art. 14: "Banks utilizing the services of another Bank: acsume no liability or responsibility (unless they themselves are at fault) should the instruetions they instruct not be carried out exactly, even if they have themselves talson the initiative in the choice of their correspondent." 
pondent bank-perhaps even the issuer's foreign branch. ${ }^{143}$ The isster is, then, seemingly absolved from any liability should its correspondent misstate the terms of the letter of credit to the beneficiary or refuse to honor complying drafts. ${ }^{144}$ This is true although the issuer may have chosen the correspondent without prior arrangement with the customer and although the issuer may derive some benefit in establishing a business relationship with the correspondent. ${ }^{145}$

Thus under the Code, the customer may find himself wholly unable to recover damages. ${ }^{140}$ Or at best he may be forced to litigate in a foreign jurisdiction against an unknown bank. Yet the damage actually suffered by the customer may be severe. The correspondent's actions may even given the beneficiary a chance to repudiate his underlying sales contract with the customer for the latter's failure to establish and receive payment under a proper credit. ${ }^{147} \Lambda$ more desirable rule would make the issuer clearly responsible for acts of its branches, and at least for acts of correspondents not dealing directly with the customer. The issuer could then recover his loss from the correspondent.

\section{Beneficiary v. Issuer}

A beneficiary may recover damages from an issuer where the latter has improperly dishonored drafts or, prior to the presentation of drafts, has wrongfully repudiated its obligations under the irrevocable letter of credit.

143. Earlier drafts included a statement that issuer was liable for the acts of its own branches, but this was deliberately deleted. See 1951 DrAFT \& 5-112; 1950 DratT § 5-112; 1949 DRAFT § 4-109.

144. § 5-107(3). Compare with The Bank Collection Code $\$ 2$ 's codification of the so-called "Massachusetts" rule that each bank is responsible for its own negligence but not for the negligence of any other bank along the collection process. See also linNL DRAFT \& 4-202(3).

145. Often seller will stipulate with buyer for confirmation by a particular bank in his country, in which case buyer will make arrangements with issuer for confirmation by that bank. Confirming bank will charge a fee to the issuer, who will in turn charge the buyer. As a rule, when mere notification is desired, the seller will not designate a particular bank. And buyer will then normally not specify any particular bank of notificittion. Issuer will be free to choose the notifying bank, which may in fact be its own branch. InTERviews. For an instance where the customer nominated the notifying correspondent bank, see Equitable Trust Co. of New York v. Dawson Partncrs, Lotd., 25 L1. L. Rep. 90 (C.A.), aff'd, 27 Ll. L. Rep. 49 (H.L. 1926); and where the issutur advised through its own choice of correspondent, Oelbermann v. National City Bank of New York, 79 F.2d 534 (2d Cir. 1936). See generally DAvis 92 et scq.

146. Despite the fact that the issuer is not liable for actions of the correspondent, it does not follow that the issuer is entitled to reimbursement when it has received noncomplying documentary drafts from its correspondent. Payment would not scem to be "duly made" to the correspondent bank under $\$ 5-107$ (2). See Equitable Trust Co. of New York v. Dawson Partners, Ltd., 25 Ll. L. Rep. 90, aff'd, 27 Ll. L. Rep. 49 (H.L. 1926) (permitting customer to refuse).

147. See FInal DRAFt $\$ 2-325(1)$. See also Obrecht v. Crawford, 175 Md. 385, 2 A.2d 1 (1938). 
Under either type of case, problems are raised as to whether there is a duty to mitigate and whether incidental damages will be allowed.

ITrongful dishonor of drafts. Under American case law a luteneficiary's measure of damages for wrongful dishonor of drafts is usually held to be the same as a seller's damages upon a buyer's breach of contract. ${ }^{145}$ Where the beneficiary resells the goods (or documents of title), he is allowed the difference between the amount of the dishonored draft and the proceeds of the sale, plus any incidental expenses incurred. ${ }^{140}$

Some American cases speal of the duty to mitigate damages, where possible, by resale. ${ }^{150}$ Several English cases flatly deny this duty and would always allow the beneficiary to recover the face amounts of the drafts with incidental expenses. ${ }^{151}$ These decisions are based on the rationale that one of the objects of letters of credit financing is the certainty of obtaining the face amount of tendered drafts without controversy. ${ }^{162}$ Clearly whatever the view, the beneficiary is awarded damages for his reasonable incidental expenses. ${ }^{183} \mathrm{He}$ is not restricted to mere recovery of the face amount of the drafts.

Code treatment of damages seems to light on a mongrel rule. Section 5116 (1) states that the issuer is liable to the holder for the face amount of the drafts and stands, with respect to documents, in "the position of a seller" under Section 2-707 of the Code. Section 2-707 permits "a person in the position of a seller" to resell the goods. ${ }^{164}$ or, in this case, apparently either

148. See, e.g., Riggs v. Lindsay, 7 Cranch 500 (U.S. 1813); De Souca v. Crodier First Nat. Bank, 23 F.2d 11 S (N.D. Cal. 1927), revid on other grousts, 27 F.2d 4 ti2 (9th Cir. 1928).

149. E.g., De Sousa v. Crocker First Nat. Bank, 23 F.2d 118, 122 (N.D. Cal. 1927), reid on other grounds, 27 F.2d 462 (9th Cir. 1928). Aword: In re Barnod's Banling Co., Coupland's Claim, L.K. 5 Eq. 167 (1869).

150. See, e.g.. O'Meara v. National Park Eank, 239 N.Y. 386, 400, 140 N.E. 636, 640 (1925). But cf. Huber \& Co. v. Lalley Light Corp. 242 Mich. 171, 21 X.W. 793 (1928) (reimbursement action against customer; bank does not have to resell-i.s., "realize on security").

151. See Stein v. Hambro's Bank, 9 Ll. L. Rep. 507 (1921), recid on olfac grousds, 10 L1. L. Rep. 529 (C.A. 1922); Belgian Grain \& Pruduce Co. v. Cos \& Co., 1 LI. L. Rep. 256 (C.A. 1919).

152. See Belgian Grain \& Produce Co. v. Cox \& Co., 1 Ll. L. Rep. 250 (C.A. 1919).

153. See, e.g., Riggs v. Lindsay, 7 Cranch 500 (U.S. 1813). And see De Sousa v. Crocker First Nat. Bank, 23 F.2d 118, 122 (N.D. Cal. 1927), revid on other grounds, 27 F.2d 462 (9th Cir. 1928); In re Barned's Eanling Co., Coupland's Claim, L.R. 5 Eq. 167,169 (1869). But note the distinction when the draft drawn under the credit is accepted and then dishonored. This situation presumably would fall undor the regular rules of negotiable instruments, where the holder would be entitled to claim only the money value stated on the instrument, interest from the time of presentmunt for payment, and expenses of notice and protest. See Davis 120-4. See also, for Cule pruvisions related to rights and duties after non-payment of accepted drafts, FinaL. DMMr $\$ 3-1 \geq 2$ (accrual of cause of action and interest).

154. $\$ 2-706$ (to which $\$ 2-707$ makes reference). Section 2-707 also gives the persun in the position of a seller a right to stoppage in transit ly referral to $\$ 2-705$. 
goods or documents of title. He can also recover such incidental damages as are commercially reasonable-storage charges, transportation charges, and the like. ${ }^{155}$ Consequently, the holder seems to have the choice of suing issuer for the face amount of the draft and turning documents over to the court, or selling the documents and recovering the difference between the proceeds of the resale and the face value of the draft. There is apparently no duty to resell. ${ }^{156}$ But in fact Article 5 will force such resale in most instances. For Section 5-116(3) limits "recovery" to the face amount of the draft. ${ }^{167}$ Thus in a suit on the draft for its face amount, incidental expenses would be excluded.

Apparently the Code is attempting to lay down the rule that issucr's liability is not to exceed the sum written on the face of the draft. ${ }^{158}$ Thus if the holder actually resells to a third person, he may still sue the issuer and recover the difference between the proceeds of the sale and the amount of the draft plus expenses. Total recovery from all sources may then exceed the face amount of the draft, but the amount recovered from the issucr will not exceed the face amount of the draft. Since the holder will almost invariably desire to recover incidental damages, which are usually substantial in oversens shipments, he will have to resell.

Perhaps the Code should require the holder to mitigate his damages by attempting to resell. ${ }^{159}$ But a barely decipherable indirect method is hardly the way to impose the obligation. And the present rule may cause the holder injury if he is unable to resell or if the total loss suffered exceeds the sum of resale proceeds and recovery on the draft. Furthermore, the issuing bank on a literal interpretation of Section 5-116(3) need pay no interest from the date of wrongful dishonor when the holder sues for the face amount of the draft. The Code attempts to justify the limitations by stating that "ptrblic policy requires that liabilities of banks be definite and knowable."100 This policy is probably predicated upon the fear that extended liability may jeopardize existing low rates. But, in fact, present rates are set without such

155. $§ 2-710$ (by referral from $\S 2-707$ ).

156. The resale section ( $\$ 2-706)$ is phrased permissively. See 1946 FEd. DrAFT $\S 10$ ("The beneficiary is under no duty to mitigate"-this provision was bracketed for possible inclusion). But see text at note 160 infra.

157. "In no event shall recovery exceed the amount of the credit or the draft as the case may be." FINAL DRAFT \& 5-116(3). See 1951 Draft $\$ 5-124$ (substantially the same provisions of FINAL DrafT $\$ \$ 5-116(1)$, (2), but no limitation of "recovery"); 1950 DrAFr \& 5-124 (states only a liability "to any aggrieved party for the face amount of the draft" without mention of the right to be in the position of a seller); 1949 Drafr $\$ 4-125$ (holder's rights "with respect to any goods" are those of a seller after "total breach" of a contract).

158. "Subsection (3) states the limit of the issuer's liability. Issuers of credits arc generally banks; public policy requires that the liabilities of banks be definite and knowable; therefore damages exceeding the amount of the draft or of the credit are forbidden." (Emphasis added). Final Draft § 5-116, comment 4.

159. Ibid.

160. Ibid. 
limitation of liability. And since denial of incidental damages may merely shift loss from the party responsible for that loss to an innocent one, there appears to be a more compelling public policy for granting full recovery. There is certainly strong public policy for stating clearly what is intended.

Repudiation. An issuing bank may attempt to repudiate its obligations under a letter of credit. It may explicitly assert its repudiation of the whole credit $;^{161}$ or it may dishonor one draft under such circumstances as to indicate an intent to repudiate the entire credit. ${ }^{102}$

Section 5-116(2) of the Code sets out an "immediate right of action" for the beneficiary when an issuing bank repudiates an irrevocable credit.103 His remedies against the bank, the section further suggests, are the same as those which a seller would have against a repudiating buyer under Article 2 of the Code. ${ }^{164}$ But by its cross-referencing, Article 5 creates uncertainty as to whether all the seller's damage measures are available to the beneficiary.

The primary remedy of the Code, resale after breach accompanied by recovery for actual loss, is clearly available by direct reference in the body

161. See Foglino v. Webster, 217 App. Div. 282, 216 N.Y. Supp. 225 (1st Dep't), modified, 244 N.Y. 516, 155 N.E. 878 (1926). See also Bril v. Suomen Pankli Finlands Bank, 199 Misc. 11, 97 N.Y.S.2d 22 (Sup. Ct. 1950) ("suit for anticipatory breach").

162. See Urquhart, Iindsay \& Co. v. Eastern Bank, [1922] 1 K.B. 318, 323.

163. Section 5-116(2) speaks of repudiation without further elaboration. There is no problem as to the applicability of the section when the issuer flatly states his repudiation of the letter of credit. Nor is there difficulty when the issuer rejects one draft covering the face amount of the letter of credit under such circumstances as indicate an intent to refure ever to honor; for, in this event, the beneficiary may treat it as a wrongful dishonor under $\$ 5-116(1)$.

Difficulty arises when a letter of credit calls for a series of drafts, one of which is rejected outright or wrongfully dishonored. The analogy is to the installment contract; and, in fact, the credit will in these instances usually arise from an installment sales contract. Section 5-116(2) does not refer directly to the installment breach section, \$ 2-612. It does, however, refer to $\$ 2-610$ (anticipatory breach section), which sets up its own criterion for outright repudiation of a performance and refers to $\$ 2-612$, which sets up adequate standards of materiality to cover the wrongful dishonor situation. $C$. Doalger v. Battery Park Nat. Bank, 201 App. Div. 515, 194 N.Y. Supp. 582 (1st Dep't 1922) (installment contract covered; repudiation five days before credit expires; damage issue decided on the basis of repudiation of whole credit at expiration date rather than on the basis of "anticipatory breach").

164. "If an issuing bank repudiates an irrevocable credit, the beneficiary has an immediate right of action and with respect to any documents may proceed lilse a seller after repudiation by the buyer (Sections 2-610, 2-611, and 2-703 through 2-705)." Final Draft \$ 5-116(2).

The ambiguity of $\$ 5-116(2)$ 's use of the terms "with respect to any doeuments" is partly clarified by a comment to the section, which states that it applies to tie "goods" represented by the documents. Final. Draft $\$ 5-116$, comment 2 . Consequently, it doss not appear to matter, for the purpose of the remedies given, that documents are, or ever will be, in existence. This conclusion is further strengthencd by the referral in $\$ 5-116(2)$ to $\$ 2-610$, which sets out the remedies for "anticipatory repudiation." See FINAL DRAFT $\$ 2-610$, and comments thereto. 
of Section 5-116(2) to relevent sections of Article 2.105 Thus, when goods have been identified to the letter of credit transaction, the beneficiary can resell those goods and recover the difference between the face amount of the credit and the resale price ${ }^{160}$ plus incidental expenses. ${ }^{167}$ And if goods are unfinished or in the process of procurement, he can ready them for resale, so long as in sound business judgment completion would not materially increase his damages. ${ }^{108}$ Moreover, under the resale provision, if goods are not in existence, the beneficiary may recover the difference between the face amount of the letter of credit and the sale price under a new contract which he enters to cover the same goods. ${ }^{169}$

But it is uncertain whether the drafters of Article 5 intended to give beneficiaries three other alternative measures of damages open to sellers after buyer repudiation: (1) the general damage measure for "non-acceptance"-the difference between the letter of credit price and the market price of the goods; ;70 (2) the profit, measured by the difference between the face amount of the letter of credit and expenses; ${ }^{171}$ or (3) the price, i.c., the face amount of the letter of credit. ${ }^{172}$

Doubt as to the availability of these alternative damage measurements stems from the Code's draftsmanship. In enumerating the sections of $\Lambda$ rticle 2 under which the beneficiary may "proceed like a seller," Section 5-116(2) does not refer directly to Sections 2-708 and 2-709, ${ }^{173}$ which provide for

165. § 2-706. See also § 2-703 ("index section" of all seller's remedies); and $\S 2-610$ cross-referencing to $\$ 2-703$ ).

The beneficiary is also explicitly given the power to stop in transit $(\$ 2-705)$.

166. § 2-706(1).

167. Ibid. (referring in the text specifically to the right to incidental expenses under \$ 2-710). Any expenses saved in consequences of the issuer's breach must be deducted. § 2-706(1).

168. \& 2-704.

169. § 2-706(2) ("The resale must be reasonably identified as referring to the broken contract"). See also $\$ 2-706$, comment 6 (subsection (2) applies to "anticipatory breach").

170. See Foglino v. Webster, 244 N.Y. 516, 155 N.E. 878, modifying 217 App. Div. 282, 216 N.Y. Supp. 225 (1st Dep't 1926). The Court of Appeals awarded the beneficiary the difference between the amount stated on the letter of credit and the market price. The lower court had allowed a measure based on the difference between the amount of the credit and the amount which the beneficiary had contracted to pay his supplier. Since the market had dropped considerably below the price which beneficiary had agreed to pay his: supplier, the beneficiary recovered much more under the Court of Appeals' measure. For a thorough analysis of the damage measures for "non-acceptance," see Comment, Remedies for Total Brcach of Contract under the Uniform Revised Sales Ach, 57 Yal: L.J. 1360, $1370-7$ (1948). See also Final DRAFT $\$ 2-708$, and comments thereto; and note 181 infra.

171. The profit measure is also considered a measure for "non-acceptance." Sec Final Draft \& 2-708; UntFora SAles ACT \& 64(3), as interpreted in Torkonian v. Russeil, 90 Conn. 481,97 At1. 760 (1916), 120 A.L.R. 1189 (1939). See note 181 infra. 172. See Final Draft $\$ 2-709$. See discussion of the price action in Comment, 57 YALE L.J. 1360, 1369-70 (1948).

173. See note 164 supra. 
the three alternative measures to the resale measure of damages. But Section 5-116(2) does refer directly to an "index section,"174 which gathers together in one place "all the remedies open to a seller for any breach by the buyer." Incorporated in that index section are references to the remedies of both Sections $2-708^{175}$ and 2-709. ${ }^{176}$ However, reference is also made in the index section to the resale sections ${ }^{177}$ and two other sections, ${ }^{178}$ to which specific cross-references are made in the body of Section $5-116(2) .^{170}$ So a court, seeking to divine the drafters' intent, might with almost equal force support a decision either to grant or to deny the remedies of Section 2-70S and 2-709 to a seller injured by a repudiation of a letter of credit.

Should the courts interpret Section 5-116(2) of Article 5 as excluding the remedies of Sections 2-708 and 2-709, the resultant denial of profit and price actions might seriously injure some seller-beneficiaries. When resale is impossible, recovery of the price may be essential to compensate the injured seller. ${ }^{180}$ And lost profit is the only measure which would allow recovery for loss when the beneficiary resells goods which, for all practical purposes, are of unlimited supply at or near the letter of credit face amount. ${ }^{181}$

174. $\$ 2-703$.

175. $\$ 2-703(\mathrm{e})$.

176. Ibid.

177. $\$ 2-706$. See incorporation in $\$ 2-703$ (d).

178. $\$ 2-704$ (right to identify goods to the contract); $\$ 2-705$ (stonpage in transit.) See incorporation in $\$ \$ 2-703$ (c), (b), respectively.

179. Note, too, that $\S 2-610$ establishes seller's remedies fur breach by refurring to the "index" section, $\$ 2-703$, without the further detailing of $\$ 5-116(2)$. Lilsewise it refers only to the "index section" for buyer's remedies. \$ 2-711. See Final Drart $\$ 2-610$.

180. The beneficiary may find it difficult to sell his vares at a commurcially reasonable price; rather than chance resale at a low price and subject himself to the objection that his resale did not meet the standards set out by $\$ 2-706(1)$, he may hold on to the goods. Exclusion of the price mensure, consequently, may furce the wronged seller into a position of selling in such a way as to cast doubt under normal circumstances on his good faith. See the discussion of the "complcmentary" nature of the price action to resale in Comment, 57 YALE L.J. 13tU, 1369 (1948).

181. Under $\$ 2-708$ the first measure for "non-acceptance" is contract less marliet price at time and place for tender (or in the case of "anticipatory repudiation," the time of learning of the repudiation, if trial occurs before the time of completed periormanio - see $\$ 2-723(1)$ ). Absence of this measure should not greatly disturb the buneficiary; for if he can establish a market price, he can usually resell. However, it doss climinate one advantage the seller might have-i.e., the opportunity to establish the marlet price for the purposes of the suit, to hold on to the goods nonetheless, gambling on a rise in the market to enable him to sell at a higher price later.

The measure of contract less expenses (the "profit") comes into play only whtn the first measure fails to put the seller in as good a position as performance. Fr:al Draft $\$ 2-708$. The comment for $\$ 2-708$ indicates that the codifiers had the "automobile eases" particularly in mind-i.e., where resale is at the contract price on standard items. But it has been aptly shown that whenever an item of unlimited supply is resold absve the point at which the seller makes a profit, the contract-less-espenses measure is a truer 
On the other hand, even if Sections 2-708 and 2-709 are interpreted as applicable, the face amount of the credit (the price) may not provide an adequate remedy where resale of goods is impossible, for incidental damages will be denied under the provision in Section 5-116(3) limiting recovery from an issue to the face amount of the credit. ${ }^{182}$

The rights to recovery of a beneficiary injured by the repudiation of an issuer are thus obscured by the draftsmanship of Article 5. And even the interpretation most favorable to the beneficiary would not allow recovery of incidental damages under some conditions. Such denial of full compensation appears unjustified. Having assumed a primary obligation to the beneficiary, an issuer should either satisfy its obligations properly or bear full liability for the results of its own misconduct. One of the main purposes of the beneficiary in seeking a letter of credit is to receive assurance of payment from a reliable bank. ${ }^{183}$ From the bank he expects to receive payment; from it, he should recover judgment for his full injury.

\section{Conclusion}

No statute can perhaps satisfy all opinion. Nor can any draftsman hope to settle all questions. And few statements of law can be so worded that they are not open to varying interpretations. Nonetheless, bankers, business men, and lawyers might have hoped for a more distinct set of working rules than the present draft of Article 5 offers. Inexact use of terms seems to mar the clarity of its functional approach. Ambiguity in important provisions may even cause undesirable litigation. Too many rights and obligations are left to the vagaries of "banking customs." Issuing banks seem to be unduly insulated from liability. Although the mere decision to codify the law of documentary credits should be a contribution, the final draft does not do full justice to the time and effort expended during the drafting process.

tally of the seller's loss than is the contract-less-market measure. See Comment, 57 Y ALE L.J. 1360, 1371-6 (1948). The present wording of the relevant comment to $\$ 2.708$ seems aimed at broad application of the "profit" measure. See FrNal DRArt $\$ 2-708$, comment 2. For previous use of the "profit" measure, see, e.g., Torkomian v. Russell, 90 Conn. 481, 97 Atl. 760 (1916) ; Stewart v. Hansen, 62 Utah 624, 218 Pac. 959 (1923) (interpreting "special circumstances" of UNIFORM SALES ACT $\$ 64(3)$ to include the "profit" measure). Contra: e.g., Charles St. Garage Co. v. Kaplan, 312 Mass. 624, 45 N.E.2d 928 (1942). For a use that would have awarded less damages in a letter of credit case, see Foglino v. Webster, 217 App. Div. 282, 216 N.Y. Supp. 225 (1st Dep't), modified, 244 N.Y. 516, 155 N.E. 878 (1926); note 170 supra.

182. See text at notes $159-60$ supra.

183. See text at notes $24-7$ supra. 